\title{
TÜRKÜN İŞ ZİHNIYETİ ÜZERİNE BİR DENEME
}

\section{Öz}

Kenan GÖÇER*

İktisat tarihi çalışmalarının alt alanı olan iktisat zihniyeti, Sabri F. Ülgener'den beri, iktisat tarihi ve iktisadi düşünce tarihi alanında Ahmet Tabakoğlu ve Ahmet G. Sayar gibi isimler hariç, üzerinde çok az çalışılan bir alan olmuştur. Osmanlı veya Türk iktisat zihniyeti olarak değinilen bu alan, M. Weber, W. Sombart ve R.H. Tawney'nin etkisiyle daha çok din üzerinden açıklanmaya çalışılmıştır. Burada yapılmaya çalıșılan açıklama ise toplumsal kültürü esas almıștır. Toplumsal kültür ile kastedilen Türkçe olarak dil, bütüncül ve tekilsel kültürdür. Türkçe'deki "iş"in dil ve iktisadi zihniyetteki izdüşümü ortaya konurken, Hüseyin R. Göktaş’ın Türkçe ve Murat Önderman'ın kolektivist ve tekilsel kültür ile sosyal kontrol hakkındaki görüşlerinden yola çıkılmıştır. Söz konusu kültür bağlamında Türkler için bir tarih dönemlendirmesi ve isimlendirme teklifi ile konu nihayete erdirilmiştir.

Anahtar Kelimeler: Türk/Türkçe, İş, İktisat Zihniyeti, Sosyal Kontrol, Kolektivist Kültür.

\section{An Essay on the Work Mentality of Turkish People}

\begin{abstract}
The economic mentality, which is a subfield of economic history studies, has been a little worked area on itself since Sabri F. Ülgener, except names such as Ahmet Tabakoğlu and Ahmet G. Sayar in economic history and history of economic thought area. This area, referred to as the Ottoman or Turkish economic mentality, was tried to be explained more by religion with M. Weber, W. Sombart and R.H. Tawney's influence. The explanation to be made here is based on social culture. Social culture refers to language as Turkish, holistic and particularist culture. It is moved from Hüseyin R. Göktaş's Turkish as language and Murat Önderman's views on collectivist and particularist culture and social control while it is presented economic mentality of the "work" in Turkish and its projection on language. In the context of culture, the subject has been finalized with a proposal for a history period and a naming for Turks.
\end{abstract}

Keywords: Turkish, Work, Economic Mentality, Social Control, Collectivist Culture.

* Dr. Öğr. Üyesi, Sakarya Üniversitesi, Kaynarca Uygulamalı Bilimler

Yüksekokulu, kenangocer@sakarya.edu.tr 


\section{Giriş}

Türk iktisat zihniyetine ilişkin çalışmaların, iktisat tarihi alanında yok denecek kadar az çalışılan bir alan olduğu bile söylenebilir. Var olanlar da büyük ölçüde Osmanlı dönemini merkeze alan çalışmalardır. Osmanlı iktisat zihniyetine ilişkin ilk metinler, iktisat tarihçisi ve/veya sosyolog Sabri F. Ülgener'e aittir. Ülgener, adını sonradan değiştirdiği çalışmasında, ${ }^{1}$ Osmanlı'nın iktisadi açıdan çözülmesinde/gerilemesinde İslam'ın değil, batınî bir tasavvuf anlayışının etkili olduğunu tartışır. Tasavvuf özelinde de olsa dine yapılan bu vurgu, aslında Max Weber'in meşhur eserinde $^{2}$ ifade edilen kapitalistleşmeyi Protestanlık mezhebi üzerinden açıklanmasına, ${ }^{3}$ Osmanlı özelinde kapitalistleşememenin bir cevabıdır ve bu cevabı hayatı boyunca diğer eserlerinde de, ${ }^{4}$ özel olarak sürdürmüştür.

Ülgener'i, Osmanlı'nın kapitalistleşememesini ${ }^{5}$ din üzerinden açıklamaya iten sadece Weber değildir. Werner Sombart ilişkiyi Yahudiler üzerinden kurmakta ${ }^{6}$, Richard H. Tawney ise daha ters bir mantıkla kapitalistleşmenin bizatihi kendisinin Protestanlığa

\footnotetext{
1 Sabri F. Ülgener, İktisadi Çözülmenin Ahlak ve Zihniyet Dünyası (İstanbul: Derin Yayınları, [1951] 2006).

2 Max Weber, The Protestant Ethic and the Spirit of Capitalism, çev. Talcott Parsons (London \& New York: Routledge, [1904] 2005).

${ }^{3}$ Ayrıntılı tartışma için bkz. Lütfi Sunar, "Weber'in İktisat Sosyolojisi: Uygarlığı Anlamanın Anahtarı Olarak İktisadi Zihniyet," Sosyoloji Konferansları 45, (2012): 19-42.

4 Ülgener, Zihniyet ve Din: İslâm Tasavvuf ve Çözülme Devri Íktisat Ahlâkı (İstanbul: Derin Yayınları, [1981] 2015).

5 Gerek "Osmanlı toplumsal yapısında kapitalizmin gelişmesini engelleyen faktörler" olarak ifadesini bulan kapitalistleşememe olgusunun Ülgener'in ana temalarından olmasını ve gerekse sosyal bilimlerin pek çok dalı (iktisat, sosyoloji, tarih ve edebiyat) üzerinden konunun yetkin tartışmasını izlemek için bkz. Lütfi Sunar, "A Weberian Critique of Weber: Re-Evaluation of Sabri F. Ülgener's Studies on Socio-Economic Structure of Turkey," Economics and Political Economy 2, sy. 1 (2015): 186-196.

6 Werner Sombart, Yahudiler ve Modern Kapitalizm, çev. Sabri Gürses (İstanbul: Küre, [1902] 2016).
} 
neden olduğunu7 ${ }^{7}$ söylemektedir. Ancak, yine bir Ülgener takipçisi ve iktisadi düşünce tarihçisi olan Ahmet Güner Sayar, hocası Ülgener'in din (İslam, tasavvuf ve melâmîlik) vurgusuna bir şeyi daha ilave etmiştir: Türk töresi. Sayar'a göre gerek Türk töresi, gerekse tasavvuf, anti-merkantil ilkeler çerçevesinde birleştirdiğinden, aranan "birey" bir türlü ortaya çıkamamıştır. ${ }^{8} \mathrm{Bir}$ iktisat tarihçisi olan Ahmet Tabakoğlu ise kapitalistleş(e)meme olgusunu ahilik üzerinden dine bağlamıştır. ${ }^{9}$ Oğuz Adanır, ne bir tarihçi, ne iktisat tarihçisi ve ne de iktisadi düşünce tarihçisi olmamasına rağmen aynı olguyu iktisat zihniyeti çerçevesinde tartışmıștır. Adanır, Osmanlı iktisat zihniyetini din ve tasavvuf üzerinden değil, kültürü merkeze alarak bütüncül bir bakış açısıyla ele almıştır. ${ }^{10}$ Adanır, antropolog Marcel Mauss'un bilim dünyasına 1925'te tanıttığ 1 potlaç olgusunun Türk iktisat zihniyetindeki köklerini yağma veya han-ı yağma gibi karşılıkları üzerinden izini sürerek ispat etmeye çalışmıştır.

Şimdiye kadar yapılan çalışmalara kısaca değindiğim bu girişten güç alarak yapmaya çalışacağım şey, -Adanır'ın çalışması hariç tutulursa- mümkün olduğunca iki yönden farklı olacak. Birincisi, Türkün iktisadi zihniyetini dini açıklama11 yoluyla yapmak yerine, dil üzerinden kültürel bir açılama geliştirmeye çalışacağım. İkincisi, yapılageldiği üzere Osmanlı iktisat zihniyeti üzerinden değil, Türkün/Türklerin/Türkçenin iktisat/iş zihniyeti üzerinde durmaya çalışacağım. Nihayetinde zihniyet, dilin

\footnotetext{
7 Richard H. Tawney, Religion and the Rise of Capitalism (New York: Harcourt, Brace and World Inc., [1926] 1954).

${ }^{8}$ Ahmet Güner Sayar, Osmanlı'dan 21. Yüzyıla (İstanbul: Ötüken Neşriyat, 2001); Ahmet Güner Sayar, Osmanlı Íktisat Düşüncesinin Çağdaşlaşması (İstanbul: Ötüken Neşriyat, 2000).

${ }_{9}^{9}$ Ahmet Tabakoğlu, Íktisat Tarihi (İstanbul: Kitabevi, 2005a.); Ahmet Tabakoğlu, İslâm Íktisadı (İstanbul: Kitabevi, 2005b); Ahmet Tabakoğlu, Türk Iktisat Tarihi (İstanbul: Dergâh Yayınlarl, 2010).

10 Oğuz Adanır, Eski Dünyaya Yeni Bir Bakış (Ankara: Doğu Batı Yayınları, 2010).

${ }^{11}$ Ancak iktisat zihniyetine ilişkin dini açıklamayı esas alan son çalışmaların da belirtilmesi gerekir: Kenan Göçer, "Kuran'daki Arz ve Dünya Kavramlarının Osmanlı İktisat Zihniyeti Üzerine Etkisi," 15. Uluslararası Türk Dünyası Sosyal Bilimler Kongresi (Moldova: 11-12 Eylül 2017, Gagauziya, 2017), 70-82; Hasan H. Aygül, Zihniyet Din ve İktisat (İstanbul: Açlım Kitap, 2014).
} 
yansıması olduğuna göre ${ }^{12}$ dilin kökü de, Türkün/Türkçe'nin tarihini verecektir. Anlaşılacağı üzere, Osmanlı'dan dişarı çıkmakla veya geriye gitmekle, dil üzerinde, daha doğrusu Türkçe'nin kendisi üzerinde hareket etmeyi kastetmiş oluyorum.

\section{Toplumsal olayları anlamada dilin imkânı}

Genel olarak dünyada ve ülkemizde hâkim olan görüşe göre dil, düşünceyi aktaran ve iletişimi kuran bir araçtır. ${ }^{13}$ Bu yönüyle, nesne olarak görülen 'dil'e egemen olanın, bir taraftan öznenin kendisi olması, bir taraftan da öznenin dile ait olmasının ${ }^{14}$ gerçekliği bir arada düşünüldügünde, sosyal bilimlerin analizinde elverdiğince dile dönmenin bir yükümlülük olduğu hemen fark edilecektir. Heidegger, "dilin, varlığın evi" olduğunu söylerken, Bachelard da "insanların [bu] evi"nin "dünyaya açıl"dığına ${ }^{15}$ işaret eder. Dünyaya açllan dil, elbette tarih içinde ancak varlık olarak açlır. Nihayetinde bu açılma yorumlardan bir yorumdur. Habermas'a göre dil, sadece iletişim kurmaz. 0 bir hükmetme ve güç aracıdır. Düzenli güç ilişkilerini meşrulaştırır. Toplumsal hareketlerin anlaşlabilmesi için nesnel ortam dil, emek ve egemenlikten oluşur. ${ }^{16}$

Mekanik dil görüşü (araçsal, her türlü mükemmelleştirilebilir, ruhsuz bir makine gibi yap-tak yapılabilir) kabul edildiğinde, onun kesinliğini ve belirli bir yasaya göre işlediğini kabul etmek durumunda kalacağız. Oysa kelimeler buna direnir. Onlar tek bir anlamı almaz ve o anlamlar, farklı nüanslarla da olsa pek çok başka anlamaları içerebilir. Hatta zamanla o

12 Jean Paul Roux, Türklerin Tarihi Pasifik'ten Akdeniz'e 2000 Yll, çev. Lale A. Özcan (İstanbul: Kabalcı, 2015), 27.

13 Gökhan Yavuz Demir, Sosyal Bir Fenomen Olarak Dilin Belirsizliği (İstanbul: İthaki, 2015), 9.

14 Demir, Sosyal Bir Fenomen Olarak Dilin Belirsizliği, 11.

15 Gaston Bachelard, Mekânın Poetikası, çev. Alp Tümertekin (İstanbul: Kesit Yayınları, 1996), 91.

16 Besim F. Dellaloğlu, Toplumsalın Yeniden Yapılanması (İstanbul: Bağlam Yayıncılık, 1998), 70. 
anlamlar yerini başka anlamlara da bırakabilir. ${ }^{17}$ Buna karşıt olarak organizmacı dil görüşü (tarihsel, devingen, canlı, ölümlü, oyuna açık, yapısal) ise, her şeyin hareket halinde olduğundan yola çıkarak bir oluşu (devingenliği) ve akışkanlığı içerdiğini vurgular. Peki, bu akışkanlık hiçbir şekilde bir düzen, sistem veya rasyonalite içermez mi?

Bu soruyu Gökhan Yavuz Demir, Sosyal Bir Fenomen Olarak Dilin Belirsizliği'nde kesin olarak cevaplamaz. Bunun, sorunun değil, cevabın kesinsizliğinden kaynaklandığı görülmektedir. Dil bir gramer olmaklığı açısından şüphesiz ki bir sistem ve rasyonelite içerdiği kadar, anlamın bağlama göre değișebilirliği ve yeni anlamlar yüklenip eski anlamları da bırakabildiği ölçüde irrasyonelite içermektedir. Söz konusu irrasyonelitenin varlığı, onun oyuna açık, herkesi oyuna alabilen yanına da işaret ettiğini gösterir. Dil, bu cilveli yapısında kimi zaman ölçüye gelir (rasyonalite), kimi zaman da ölçüye gelmez, hesap edilemez (irrasyonelite) bir özellik gösterir. Bu, onun kimi zaman özne, kimi zaman da nesne olarak görünmesine benzetilebilir. Ya da kimi zaman kozmos, kimi zaman da kaos olarak, fakat her hâlükârda kendine özgü bir mantık içerisinde değișerek ilerler.

Biraz da insanoğlunun kurduğu siyasal ve ekonomik düzenlere benzemektedir. Tarih içinde kurulan söz konusu düzenler, tıpkı dilde olduğu gibi, kimi zaman onun bir mantığını bularak, kimi zaman da bulmadan değişime uğramaktadır. Dildeki düzen ile toplumsal düzenin paralel seyrettiği söylenebilir. Dilin oyuna açıklığı, "yer değiştiren gölge" gibi her farklı bağlamda yeni anlamlar üretmektedir. Onu oyun yapan ana özellik, kelimelerin sözlük anlamları dışında yeni anlamlar kazanabilmesidir. "Hayat formları" değiştikçe anlam da değişir. Ama kullanılan dizge, yapısını büyük ölçüde korur. "Sadece hayatın akıntısı içinde kelimelerin anlamları vardır."18 Wittgenstein'a göre "dil praksistir ve praksis de kullanım tarzıdır."19 Diyalektik bir ilişki içinde hayat

17 Michel Butor, Michel Butor Üstüne Doğaçlamalar, çev. İsmail Yerguz (İstanbul: YKY, 1996), 196.

18 Demir, Sosyal Bir Fenomen Olarak Dilin Belirsizliği,105.

19 Demir, Sosyal Bir Fenomen Olarak Dilin Belirsizliği,107. 
formları değişirse dilin kuralları, dilin kuralları değişirse hayat formları değişir. ${ }^{20}$ Almanca'nın düzenli bir dil olmasının, Almanların düzenli ve disiplinli bir kafa yapısına neden olmasi ${ }^{21}$ örneğinde olduğu ve benzer görüşleri Fransız filozof Etienne de Condillac ve onun çağdaşı Alman Johann Gotfried Herder'in de ifade ettiği gibi: "Bir milletin düşünce yapısını en iyi yansıtan şey dilinin fizyonomisidir."22 Ulusun tinsel gücüne șekil vermede temel eyleyici olan dil, diyor Taylan Altuğ, akıl ile eş zamanlı olarak meydana gelir. 23

Kelimelerin anlamları çoğu kez yenilense de, dilin değişmeyen bir sistem üzerinde işlediği yukarıda farklı biçimde de olsa ifade edilmiş olmalıdır. Dilin değişmeyen sistemi ile hayat formları arasında bir bağ var mıdır? Varsa nedir ve ne ölçüde bu bağ genelleştirilebilir? Aşağıda, Türkçe üzerinden büyük ölçüde bu soruları sormaya ve elden geldiğince de cevabını vermeye veya kültürle benzeşen yanları üzerinde durmaya çalışacağım.

\section{Türk'ün iktisat zihniyetini anlamada Türkçe’nin imkânı}

\section{1. "Ş" teksesi}

Türk'ün iktisat zihniyetini anlamada felsefi anlamda bir özcülüğe düşmeden, Türkçe'nin imkânı olarak temel bir iddiamı sunmak istiyorum. Buna da iş önermesi adını teklif ediyorum. Önerme şudur:

“Türkler, büyük ölçüde 'iş'teșlik 'ş'(se)sine başvurmadan bir iş yapamazlar."

Ancak bu önermeyi açmadan, 'Türk iş zihniyeti' ifadesinde geçen her terimi nasıl anlamlandırdığımı/anladığımı belirtmem gerekir. Türk ile anasından Türkçe öğrenmiş ve Türkçe

\footnotetext{
20 Demir, Sosyal Bir Fenomen Olarak Dilin Belirsizliği,108.

${ }^{21}$ Guy Deutscher, Dilin Aynasından, çev. Cemal Yardımcı (İstanbul: Metis, 2013), 9.

22 Deutscher, Dilin Aynasindan, 11.

23 Taylan Altuğ, Dile Gelen Felsefe (İstanbul: YKY, 2017), 60.
} 
konuşanların ortamında Türkçe konuşarak yaşayan kişiyi ${ }^{24}$; iş ile Türklerin her tekinin ailesel geçimini sağlamak üzere diğer kişilerle ortaklaşa/birlikte yaptıkları şeyi/faaliyeti ya da iş-teşliğin 'iş'ini; zihniyet ile de kendisini farkında olmadan kuşatan, hareket, söylem, tavır ve jest-mimiklerine yansıyan, iş tutuş tarzını belirleyen eyleme biçimlerini kastediyorum. Ailenin ise eş ve kardeş, aileyi aşan ilişkilerin de arkadaşlık temelinde bir kandaşlık ve akrabalık yapısı oluşturduğu hatırlanmalıdır.

$\mathrm{Bu}$ önermeyle basit olarak şunu ifade etmek istiyorum: Anlaşmak, savaşmak, dövüşmek, çarpışmak, barışmak, birleşmek, işlemek, çalışmak, alış-veriş yapmak vb. örneklerinde olduğu gibi Türkçe'de iş-teşlik 'ş' sesi, birden fazla kişinin yaptığı işleri ifade etmede kullanılmaktadır. Íki kişi ve iki tarafin bir iş veya birlikteliği doğurduğunu, buradan hareketle iş-teşliğe başvurmadan bir iş yapılama-dığı/yacağı da ortadadır. Bu birlikte-liği sağlayan aslında "ş" teksesidir: Kaynaştırır, çalıştırır, birleştirir, işler. Biri çok, çoğu da bir iş etrafında tek yapmış olur. Türkçe'de anlama son şeklini verenin, kök-leri şekillendirenin bu teksesler olduğunu ifade eden Hüseyin Rahmi Göktaş'a göre dil, kelimelerden değil, tekseslerden oluşur. ${ }^{25}$ Kelimeler ise dil sistemi kurulduktan sonra oluşurlar. ${ }^{26}$

Osmanlı örneğinden bakacak olursak, iktisadi anlamda ideal kişinin izini tımar sistemi içinden görmemiz uygun olabilir. Tarihsel dönemlerde değişim gösterse de, nüfusun \% 75-80 oranında çoğunluğunu reaya kesimi denilen, toprakla meşgul köylüler oluşturuyordu. Köydeki ev veya hanenin reisi ise evli erkekti. Evli erkek, eşi olan erkektir. Bu anlamda Osmanlı köylüsü için somut bir kişiliktir ev-li erkek. Eşi olmanın iktisadi anlamda önemi, kapısında bir çift öküzü (eşli öküz) olduğu anlamına da gelir ki, bu, hane reisi olarak kişinin vergi mükellefi olduğunu gösterir.

\footnotetext{
24 Anasından Türkçe öğrendiği halde, Türkçe konuşulmayan bir ortamda, örneğin yabancı ülkede bulunan kişinin bu önermenin kapsamına girmediğini belirtmeliyim.

${ }^{25}$ Hüseyin Rahmi Göktaş, Runa Simi (İstanbul: İz Yayıncılık, 2010), 85; Hüseyin Rahmi Göktaş, Zihin Evreni (İstanbul: İz Yayıncılık, 2011), 42: "Dil seslerden oluşur."

${ }^{26}$ Göktaş, Zihin Evreni, 45.
} 
Eşi olmayan yetişkin erkek, doğal olarak ev de kuramadığından (evli olmama) Osmanlı için soyut bir varlık hükmündedir. Nitekim bu kişiye Osmanlı "soyut" anlamına gelen mücerred demektedir. ${ }^{27}$ Evlenmek, erkeğin medeni bir hal değişikliğinden ziyade, iktisadi bir durum değişimine işaret ediyor. Çünkü ev-li olmayan erkeğe yine o günlerden kalma bir tabirle bekâr diyoruz. Bekâr, kâr-sız anlamındaki Farsça bî-kârın halk arasındaki söylenişidir. Ancak, bekâr erkek olan mücerredin hiçbir kazancının olmadığını söylemek de doğru değildir. Burada yapılan her genellemede daima bir 'büyük ölçüde'nin var sayıldığı unutulmamalıdır. Bu durumda Osmanlı toplumunun 4/5'ü için herhalde büyük ölçüde şu iktisadi üçgenin geçerli olduğunu söyleyebiliriz: Eş, iş ve aş.

Bilebildiğim kadarıyla Türkçe'nin kendisi üzerinde düşünmeyi kendine iş edinmiş ilk kişi olan ve bu çalışmanın da yine esin kaynağı olan Hüseyin Rahmi Göktaş, "ş" sesini ayna olarak gördügünü ve evrene bu yönüyle bir simetri kazandırdığını ifade ediyor. ${ }^{28}$ Özne veya nesnenin aynada çoğalması, simetri ve karşılıklığı doğuruyor. Çoğalmak, çok-lukla iş yapmak "ş" sesine başvurmadan nasıl yapılamıyorsa, bir "iş" yapmak için çokluğa başvurmamak da o oluyor. İş için çokluk, çokluk için de iş, birbirinin zorunlu şartları oluyor. Çokluğu burada -şimdilikbirden fazla kişi(ler) olarak kullanıyorum.

"Ş"ye tekrar dönersek; Göktaş’a göre, kendimizden bir başkası olan, kendimizin dışındaki karşımızdakine ulaşmak için bir ses çıkarmaya çalıştığımızda, bu, "s" sesinden (sen) başkası olamaz. Sesi, "nefesimiz yettiğince" uzattığımızda, nefesimiz bir süre sonra yetmezleşir ve başlangıçtaki o temiz ses, "ş"ye dönüşür. Yani "s" sesi değ-iş-ir. Değ-iş-im, değerin işteşliği, işteşlik ise mübadeledir. $\mathrm{Bu}$ anlamda iş de "ş" sesinden başka bir şey değildir. "Ş" gibi tekseslerin anlama en yakın anlam olduğunu iddia eden Göktaş, "ş teksesi bir kat daha karışıklaştırıldığında bu kez 'ç' sesi elde

27 Halil İnalcık, Osmanlı Imparatorluğu Klasik Çă̆ (1300-1600) (İstanbul: YKY, 2003), 112; Halil İnalcık, Osmanlı Imparatorluğu Toplum ve Ekonomi (İstanbul: Eren Yayıncılık, 1996), 38-48.

28 Göktaş, Zihin Evreni, 94. 
ediliyor", der. "Ç” sesini de çok, üç ve ucda görüyoruz. ${ }^{29}$ "Ş" ikiye değil, karşılıklığa, iki tarafa; "ç" ise ikiden fazlaya, üçe, uça, çoğalmaya, çokluğa, karman çormanlığa, çoluk çocuklara vs. karşllık geliyor.

"Çok"un kaça tekabül ettiği bilinemez. Ancak onun en azından ikiden fazla olduğunu anlarız. "Ş"nin ise "s"nin ('ses'lenilen sen) eşi olduğu artık iyice ortaya çıkmış olmalıdır. "Ş" bu anlamda karşılıklı il-iş-kiyi ve iş-leyişi ifade eder. Birey olarak eșini/diğerini bulmadan bir iş yapmak Türkçe'de pek mümkün gözükmemektedir. Aynı mümkün gözükmeme, öğrencinin dersine tek başına çalışamaması, çalışsa bile dışarıdan birinin (dershane, anne, baba vs.) baskısını üzerine almak istemesi, çalışacağı konuya tek başına karar verememası veya bir yönlendirme beklemesinde de görülebilir. İş, çokluğun içinde, çok civarında, çokluğun onayıyla yapılabilir. Örneğin süte yoğurt çalındığında/mayalandığında az bir yoğurt, kendisinden kat be kat fazla olan, yani çok olan sütü yoğurt yapar. Çalma işlemi, az yoğurdu çoklaştırır. Çalmak, çok tellere dokunmakla (çalmakla), sesi, söze saz ile ekler.

\section{2. Tekses ve ünlü uyumları}

Türkçe'de kelimelerin kendisinden anlam bularak çıktığı bir kökün olduğunu savunan Göktaş, bu kökün; "fiillerin, isimlerin, sıfatların, hatta bağlaçların da kökü olan bir ses" olduğunda ısrar eder. ${ }^{30}$ Ona göre köksesler, fiillerin, isimlerin, sıfatların, hatta bağlaçların köklerini (fiil kökü, isim kökü vb.), bu kökler de kendisinde türetilen veya türetilecek olan yeni fiil, isim ve sıfatları oluştururlar. Gözlük ismini ele aldığımızda, Göktaş’a göre ismin kökü 'Göz' değil de, 'Z' sesi oluyor: g-öZ/lü-k. İlk hecenin vurgu yapılan ve biten sesi kökses'tir: Z. Kökün ortada da olduğunu veya olabileceğini -kim bilir belki de kökses hep ortadadır- ifade ediyor. Köken, Göktaş'ın iddia ettiği gibi ister bahsi geçen kökseste olsun,

\footnotetext{
${ }^{29}$ Göktaş, Zihin Evreni, 36-39.

${ }^{30}$ Hüseyin Rahmi Göktaş, Bensenog Türkçenin Ruhu (İstanbul: Külliyat Yayınları, 2016), 23.
} 
isterse kelime/fiilin kökündeki/başındaki ilk seste olsun, kelime her hâlükârda ilk veya köksese eklenerek büyüyecektir.

Ancak kökseslerden fiil/isim köküne, fiil/isim kökünden de başka fiil, isim veya sıfata ulaşırken kelimeler büyük ölçüde, Türkçe'nin büyük ve küçük ünlü uyumlarına uydurulacaktır. Büyük ünlü uyumunu hatırlayacak olursak, kelimenin ilk hecesinde kalın ünlü $(\mathrm{a}, \mathrm{l}, \mathrm{o}, \mathrm{u})$ varsa, diğer hecelerdeki ünlüler de kalın; ince ünlü (e, i, ö, ü) varsa diğer hecelerdeki ünlüler de ince olacaktır. Örnek: Ayım, dayım, ağız, dayak, bacak, boyunduruk, burun, kulak, dalga, dudak, kırlangıç; beşik, bilezik, gelincik, gözlük, üzengi, vergi, sevgi, yüzük vb. ${ }^{31}$

Türk Dil Kurumu'nun resmi sitesinden küçük ünlü uyumuna ilişkin yapılan tanımlama da şöyledir: "Bir kelimede düz ünlüden sonra düz (a, e, l, i), yuvarlak ünlüden sonra yuvarlak dar (u, ü) veya düz geniş $(\mathrm{a}, \mathrm{e})$ ünlüler bulunur: Bilek, çilek, ısırmak, ılıklaşmak, kayıkçı, seslenmek, yeşil; boyunduruk, börekçi, çocuk, güreşmek, ocakçı, odun, özlemek, sürmek, vurmak, yoklamak, yorgunluk, yumurta, yüreksiz vb."32

Bu uyuma uymayan kelimelerin olmadığını iddia etmiyorum. Bir kural varsa onun istisnaları da elbette olacaktır. Bu istisnalara Türk'ün/Türkçe'nin hoşgörüsü de denebilir. Ancak, Türk (Türkçe) konuşu(lu)rken büyük ölçüde her iki ünlü kuralını da kullanımda arayacaktır. Ancak, dile girmiş yabancı kelimelerde büyük ünlü uyumu (mizan, istasyon, dükkân, gazete, sinema, birader, kestane, limon, model, otomatik, selam, tiyatro, ziyaret vb.) ve küçük ünlü uyumu (aktör, alkol, bandrol, daktilo, traktör, muzır, mühim, mümin, müzik, profesör, vb.) aranmayacaktır.

\footnotetext{
31 Türk Dil Kurumu, http://www.tdk.gov.tr/index.php?option=com_content\&id=177:Buyuk-UnluUyumu\&catid=50:yazm-kurallar (7.05.2018).

32 Türk Dil Kurumu, http://www.tdk.gov.tr/index.php?option=com_content\&view=article\&id=178: Kucuk-Unlu-Uyumu\&catid=50:yazm-kurallar\&Itemid=132 (7.05.2018).
} 
Kelimeler köksesten gövdeye ve dala doğru büyürken veya anlam kazanırken, büyük ölçüde kökende/tarihte belirlenmiş bir uyuma, uyarlar. Yabancı kelimelerde buna dikkat edilmediği görülüyor. Kelimede anlam/mana, kökün belirleyiciliğinde şekilleniyor. Ama bu şekillenme de büyük ölçüde büyük ve küçük ünlü uyumları kontrolünde yapılıyor. Elverdiğince kontrol elden bırakılmıyor. Bu kontrol için büyük bir enerji harcandığı tahmin edilebilir. Yabancı kelimelerin bu uyuma uymaması ve onlara gösterilen toleransın/hoşgörünün neden kaynaklandığını da ayrıca düşünmeye değer gözüküyor.

Kelime, anlamını köksesten başlayarak cümlede bulunduğu konumdan da alır. Bunun yanında hem cümle içindeki kelime, hem de metin içindeki cümle, anlamını, metnin bütünsel anlamından yani bağlamından yola çıkarak kazanır. $\mathrm{Bu}$ anlamda cümle, kelimelerin örgütlenme tarzı ve ilişki biçimidir. Anlam cümlede iktidarını kurar ve iktidarın yapısı ancak metnin bütününden çıkarılabilir. O sebeple metinden çekilip çıartılan bir cümlenin, kelimenin veya sesin gerçek anlamını, bağlamından koparıldığ müddetçe tam olarak bulamayız. Her ses, kelime veya cümle, metnin içindeki konumlanışına göre yeniden değer veya anlam kazanır. Bu hiçbir şekilde sesin, kelimenin veya cümlenin kendi başına bir anlamı olmadığı anlamına gelmez. Metnin bütünsel anlamını, içinde bulunduğu kültürel ortam, zihniyet dünyası ve iktidar ilişkileri verir. Bu yaklaşım tarzımız, modern psi sektörüne ${ }^{33}$ (psikoloji-psikiyatri-psikoterapi-psikanaliz) hâkim olan bireysel temelli anlayışın karşısında bir konumlanmaya benzetilebilir. Orada da kişinin yaşadığı sorunlar, sosyokültürel bir altyapıdan kaynaklı sorunlar olarak değil, bireyin özel psi sorunları olarak görülür. Aşağıda ş, ç, kökses, uyum, uyumu sağlama anlamında

\footnotetext{
33 Kavramsallaştırma ve sorunun sosyokültürel bir ortam çerçevesinde değerlendirilmesi gerektiğine ilişkin tartışma için bkz. Murat Önderman, Türkiye'de Paranoid Ethos (İstanbul: Filiz Kitabevi, 2007b), 42-83. Wilfred R. Bion da benzer kaygıdan yola çıkarak grup davranışı kavramını önerir: Wilfred R. Bion, Experiences in Groups and Other Papers (New York: Brunner-Routledge, 2004), 40.
} 
kontrol ve yabancıya toleransın kültür içindeki görünümüne değineceğim.

\section{Türklerin özellikleri, sosyal kontrol, kolektivist ve tekilci kültür}

\section{1. Türklerin özellikleri}

Tarih, bazı yönlerden zihniyete karşıdır. Tarih, genellikle zaman içindeki değişimi araştırma eğilimindeyken; zihniyet, değişmeyeni, zamana karşı bazan hiç görünmeden direnen yapıyı bulmaya çalışır. Ve bazan yapı, o kadar göz önündedir ki, ağaçlardan ormanı göremez olur insan. Yeniden hatırlatmak gerekirse bu çalışma bir tarih değil, zihniyet, iktisat zihniyeti çalışmasıdır. Bu yönüyle ormanı görme çabasıdır da diyebiliriz.

Türklerin tarih boyunca değişmeyen özellikleri, bir bakıma onların zihniyetini veya zihniyetine ilişkin ipuçlarını verir. Çünkü özellikler, nihayetinde kolay kolay değișen şeyler değildir. Jean Paul Roux, Türklerin Tarihi'nde Güney Sibirya'da yazılmış metinlerden yola çıkarak, Türklerin Afganistan'dan Anadolu'ya, Uygur halklarından Hazar Krallığı'na, Altınordu Hanlığı'ndan Osmanlı zamanına kadar aynı kalan, değișmeyen bazı özelliklerini sıralamıștır. Basitleștirirsek bunlar: "[Y] üksek onur, verilen söze sadık kalmak, ihanet edenlere karşı acımasızlık, ırkçılıktan uzak oluş, vurgulu bir askeri anlayıș ve buna uygun erdemler, savaşanlar arası dayanışma, üste kesin itaat, toplumsal sınıfların çok güçlü bir biçimde yapılandırılmış olmasıyla birlikte aralarında geçiş yapma kolaylığı, hoşgörü, tasavvuf merakı ve bir tür alaycı kuşkuculuk."34

Psikiyatrist Erol Göka, Türklerin bahsi geçen özelliklerinin pek çoğunun varlığını bugün kendi alanı üzerinden de gözlemlemiştir. ${ }^{35}$ Türklerin büyük ölçüde değişmediğini

\footnotetext{
34 Jean Paul Roux, Türklerin Tarihi Pasifik'ten Akdeniz'e 2000 Yıl, çev. Lale A. Özcan (İstanbul: Kabalcı, 2015), 27-28.

35 Erol Göka, Türk Grup Davranışı (Ankara: Aşina Kitaplar, 2006); Erol Göka, Türklerin Psikolojisi (İstanbul: Timaş, 2011); Erol Göka, Türklerde Liderlik ve Fanatizm (İstanbul: Timaş, 2009).
} 
varsaydığımız bu özellikleri, şüphesiz onun sözlü kültürden yazılı kültüre, göçerlikten yerleşikliğe, dini-mistik bir yaşamdan ${ }^{36}$ seküler bir düzene ve armağan (potlaç, yağma, bağış, ikram vb.) kültüründen ${ }^{37}$ piyasa toplumu kültürüne geçişin hâlen devam etmekte olduğunun işaretleri olarak ileri sürülebilir. Tüm bu özelliklerin Türklerin iktisat (iş) zihniyeti üzerinde etkisinin olduğuna şüphe yoktur. Fakat değişim olsa da, onların da derininde yatan ve büyük ölçüde (dil gibi) değişmediğini farkettiğimiz bu özelliklerin aynı zamanda zihniyetimizi belirlediğini veya etkilediğini söyleyebiliriz. Söz konusu zihniyeti belirlemedeki etkinlik, sosyal kontrol dolayımından geçerek gerçekleşiyor gibi görünüyor. Sosyal kontrol meselesine başvuruşumun nedeni ise daha çok Türkçe'deki büyük ve küçük ünlü uyumu fonksiyonuna benzerliği açısındandır. Ünlü uyumuna uymayan Türkçe kelimelerin istisnalarını da toplumda baskın olan kolektivistik (holistik-bütüncül) kültür tarafından uyumlaştırmanın yerine getirildiğini düşünüyorum. Așağıda, Murat Önderman'ın üzerinde durduğu gerek sosyal kontrolü, gerek kolektivist kültürü ve gerekse konuyla ilişkili diğer görüşlerini, toplum üzerindeki etkisi bakımından mesele ederek dil üzerinden Türklerin iş zihniyetinin görünür kılınmasına çalışılacaktır. Dolayısıyla, aşağıdaki kısım büyük ölçüde Önderman'ın görüşleri çerçevesinde şekillenecek ve yeri geldikçe tartışılarak bir sonuca varılmaya çalışılacak ve

\footnotetext{
${ }^{36}$ Kenan Göçer, "Melâmîliğin Türklerin İktisat Zihniyeti Üzerindeki Uzun Dönem Etkisi,” Türk Dünyası Araştırmaları 115, sy. 227 (2017): 115-132; Kenan Göçer, "Ahiliği Potlaç Kültürü Üzerinden Yeniden Düşünmek," Selçuk Üniversitesi Edebiyat Fakültesi Dergisi 37, (2017): 465-476.

${ }^{37}$ Leandro Benedini Brusadin, "The Gift Theory of Marcel Mauss and the Potlatch Ritual," The Routledge Handbook of Hospitality Studies, ed. Conrad Lashley (London: Routledge, 2016), 298-310 (27.11.2017); Alf Rehn, “Gifts, Gifting and Gift Economies," The Routledge Companion to Alternative Organization, ed. Martin Parker v.dğr., (London: Routledge, 2013), 195-209 (27.11.2017); Kojin Karatani, Dünya Tarihinin Yapısı, çev. Ali Karatay (İstanbul: Metis, 2017); Karl Polanyi, Büyük Dönüşüm, çev. Ayşe Buğra (İstanbul: İletişim, 2016); Adanır, Eski Dünyaya Yeni Bir Bakış; Kenan Göçer, "Armağan Kültürü Açısından Saatleri Ayarlama Enstitüsü'nün İktisadi Zihniyeti Üzerine,” Sosyoloji Divanı 10, (2017): 253-268.
} 
Önderman'ın görüşleri, Göktaş’ın dil yaklaşımı paralelinde açlacaktır.

\section{2. Sosyal kontrol, kolektivist ve tekilci kültür}

Öncelikle, 'sosyal kontrol'den ne anladığımızı belirtmemiz gerekir. Önderman, Joel S. Migdal'ın tanımını devralarak sosyal kontrolü, "kişilerin aksi halde davranacaklarından farklı davranmalarını sağlamak" şeklinde tanımlar. ${ }^{38}$ Onun mekanizmaları da toplumdan topluma değişiklik gösterebilir. Örneğin, Batı'da hukuk normları gibi formel sosyal kontrol mekanizmaları etkinken, Türkiye'de çevresel ilişkiler, tanıdıklık, hemşerilik, akrabalık, aynı dernek veya cemaat içinde olmaklık gibi informel sosyal kontrol mekanizmaları daha etkin görünmekte.

Kültürel yapılara ve yapı içindeki farklılıklara karşı en hassas konumda olan iktidar, Batı'da sadece karar alma, gündem oluşturma ve eylemlerin seyrini belirlemede varlığını gösterirken; Doğu'da, yukarıda sayılanlara ilaveten ve de daha vurgulu bir biçimde statü (prestij, şeref, itibar, seçkinlik, ayan/eşraf vs.) ve statüye eşlik eden her şey olarak kültürel etkilerin önemine işaret eder. ${ }^{39} \mathrm{Bu}$ anlamda Türklerin de içinde bulunduğu kültürlerde yapılan her faaliyet veya iş, bir konum, statü veya itibar elde etmeye yönelik kıyasıya ve bitimsiz bir yarış içinde olmayı zorunlu kılar. Toplumdaki egemen holistik kültürden dolayı hiçbir iş ya da faaliyet, diğer iş, faaliyet veya kişinin toplumdaki sosyal rolünden bağımsız olarak ele alınamaz.

Böyle bir toplumda iktidar kendini, diğer kişilerden bağımsız -kendinde iktidar, özerk- göremediği için kişilerarası ilişskiler ve bu ilişkilerin yöneliminde șekillenen hukuki ilişkiler yoluyla üretir. ${ }^{40}$ Adı geçen kişilerarası ilişkiler, doğal olarak devleti baba olmak devlet baba!- dışında algılayamıyor. Bu düşünce tarzı, Önderman'a

\footnotetext{
${ }^{38}$ Murat Önderman, Türkiye'de Devlet Sosyal Kontrol ve Öznellik (İstanbul: Filiz Kitabevi, 2007), 18.

39 Önderman, Türkiye'de Devlet Sosyal Kontrol ve Öznellik, 6.

40 Önderman, Türkiye'de Devlet Sosyal Kontrol ve Öznellik, 7.
} 
göre dayanağını kolektivist (birlikte yaşamcı) kültürden ${ }^{41}$ alıyor. ${ }^{42}$ Dünyadaki toplumların büyük çoğunluğunu kolektivist olarak, azını da bireyci olarak adlandırıyoruz. Kolektivist toplum, bireyin üzerindeki gücü devletin değil, ailenin oluşturduğu toplumlardır. Ancak ailenin büyüklügü de yine toplumdan topluma değişir. Hofstede'e göre bu kültürde çocuklar büyüdüklerinde kendilerini bu 'biz' grubunun bir parçası olarak düşünmeyi öğrenirler. ${ }^{43}$ Bugün bunu Türkiye'de makalelere ve diğer politik metinlere veya siyasi retoriğe egemen olan cümlelerin/söylemlerin biz ile başlayıp düşünüyoruz vs. şeklinde bitmesinde de görebiliriz. ${ }^{44}$

41 Deneyimli bir makine mühendisi olan ve Sosyal Psikoloji'de doktorasını tamamlayan Geert Hofstede, kültürden kültüre veya ulustan ulusa değişen davranış ve düşünüş farklılıklarını açıklamak için 1980'lerde 40 ülkedeki IBM servislerinde çalışanlar üzerinde 50'den fazla kültürü araştırarak vardığı sonuçları Kültürel Boyutlar Teorisi'ne dönüştürür. Buna göre altı ayrı başlıkta kültürleri sınıflandırır: 1-(Düşük-Yüksek) Güç mesafesi, 2-Bireyselci-Kolektivist yapı, 3-Belirsizlikten kaçınma (düşük-yüksek), 4-Eril-Dişil, 5-Uzun-Kısa vadeli yön belirleme ve 6-Serbestlik-Sınırlanma. Bireyselci-Kolektivist yapı ayrımında Türkiye daha çok kolektivist kültür içinde görülüyor. Bireyselci Batı kültürü "ben" merkezli, bireysel tercihlerin önem taşıdığı, kendi koyduğu sorumluluklara bireyin uyduğu, bireyin düşüncelerini doğrudan belirtebildiği, sözlü iletişimin ağırlıklı ve ayrıntılı olduğu bir kültür iken, Kolektivist kültür ise "biz" merkezli, kişiler arası ilişkilerin işten daha önemli olduğu, grubun zorladığı sorumlulukların birey tarafından gerçekleştirilmesi gerektiği, grup içi uyumun işi yapmaktan/başarmaktan daha önemli olduğu, tartışma ve eleștirilerin kişilik üzerinden algılandığı ve bu yüzden hiç hoş karşılanmadığı, sözlü iletişim kadar veya belki daha fazla jest-mimiklerin önemli olduğu, sözlü iletişimde ayrıntıya girmeyip (gerektiğinde cayabilmek için) boşlukları karşı tarafın doldurmasının istendiği bir kültür: Geert Hofstede v.dğr., Cultures and Organizations: Software of the Mind (New York \& Chicago: McGrawHill, 2010), 27-52, 89-134. Türkiye bu ayrımda kolektivist kültür içinde yer alıyor.

42 Önderman, Türkiye'de Devlet Sosyal Kontrol ve Öznellik, 6.

${ }^{43}$ Hofstede v.dğr., Cultures and Organizations: Software of the Mind, 91.

${ }^{44}$ Hatta yukarıda fark etmeden kurduğum cümlelerin yüklemlerinden birinin "adlandırıyoruz." şeklinde bitmesinde de fark edilebilir bu durum. Cümlelerimin yüklemlerinin kimi zaman "biz"i, kimi zaman da "ben"i nitelemesi, bu ikircikliğin bir göstergesi olsa gerek. Günümüzün makalelerinde yazarın kendini "ben" olarak görmesi, hakem/jüri tarafından bir haddini aşma olarak değerlendirilebilme ihtimalinin yaratacağı tedirginliğe eşlik etmiyor değil doğrusu. Bizden bene geçen yazarların metinlerindeki her iki özneyi kullanım da bu korkunun kişilerin üzerinden henüz atamadığının işareti olarak görülebilir. 
Türklerde iktidarın kolektivist kültür kaynaklı tekilselci (partikülaristik) ilişskilerden ${ }^{45}$ dolayı özerk olamayışı, hem iktidarın hem de bireylerin çok biçimli (amorf), bağlamsal bir benliğin geliștirilmesine sebep olmuştur ${ }^{46}$ diyebiliriz. İktidarın, toplumdan/bireyden ayrışmadığı için, onu yönlendirme ve onun özne olma kapasitesini hayata geçirme gücüne de sahip olamadığı görünüyor. Ancak onu etkiler: Korkutur, tabi kılar, kendi başına karar alma, düşünme ve eyleme kapasitesini yok eder. Bu durumda birey/toplum da ondan uzaklaşamaz, onun güdümünden ayrılamaz. Daha çok iktidara yönelir, yaklaşır, memuriyet dışında bir iş düşünemez olur, düşündüğünde de çevresel ilişkilerine güvenir. Güveni şekillendiren, güvenilen kişinin merkezle/kökle yakınlık derecesi veya merkeze yakınlık kurabilme kapasitesidir.

Merkezi burada fiil/isim kökü olarak da alabiliriz. Kişi/toplum bu köke (merkez) eklenerek varlığını/işini kazanır. Ancak, bu o kadar da kolay olmaz. Devlet, her ailenin ortak babası olmasına rağmen, babanın çocuklarından istediği itaate (ünlü uyumu) yakınlığı, gönüllülüğü, sürdürebilirliği ölçüsünde uyum sağlanmış olur. Ancak bu durum, bir kere sağlanan uyumun bir daha bozulmayacağı anlamına gelmeyecek, her ilişkide ve karşılaşmada tekrarlanması veya güncellenmesi gerekecektir. Birey veya toplum, itaat ettiği ölçüde korunma/güvenlik alacaktır. Buna karşılıklı bağımlılık diyoruz. Her iki taraf da bu bağımlılığa (işteşlik) muhtaçtır. Cümle, düzenin (düzgün, düzge, tüze, tüzük) kurulmasıyla oluşur. Bir cümlede kurulan düzen, her cümlede tekrarlanır. Aynı uyum (ünlü uyumu ve kök/ilk sese bağlılık) her defasında gözetilir. Çünkü her anlamda yapılan iş, herkes içindir.

45 Thomas Mautner (Ed.), “Particularism," The Penguin Dictionary of Philosophy (London: Penguin Books, 1997), "tekilcilik (particularism)” maddesinden aktaran Murat Önderman, "Türkiyede Tekilci Kültür Hukukilik ve Armağan Ekonomisi," İstanbul Üniversitesi Siyasal Bilgiler Fakültesi Dergisi 25, sy. Ekim (2001): 157-208, 158: "İlk anlamıyla ahlaki kaygıların belirli bir grup, sınıf, toplum veya ulusla sınırlanmasıdır. İkinci olarak, tekilcilik, bir davranıșın ahlakiliğini, genel bir norm veya ilkenin değil de, durumun tekil (particular) özelliklerinin belirlediğini ileri sürer." Önderman, "Türkiyede Tekilci Kültür Hukukilik ve Armağan Ekonomisi," 158: "Tekilcilik her iki görünümüyle Türkiye'deki köklü armağan ekonomisinin kültürel zeminini oluşturmaktadır." 46 Önderman, Türkiye'de Devlet Sosyal Kontrol ve Öznellik, 9. 
İşin kendi başına özerk bir yapısı veya anlamı büyük ölçüde olamaz. Kendi başınıza yaptığınız iş dahi başka ilişkilerin çevresinde veya izninde şekillenir. Bu izin yasal süreçler değildir. Ancak onu da kapsar. Fakat yasal süreçler, yasanın (tüze, tüzük) kendi başına anlamı olduğu anlamında ele alınmıyor burada. Yasaya genellikle geçiştirilmesi gereken bir formalite veya prosedür olarak bakılıyor. $\mathrm{Bu}$ formalitelerin karmaşıklığı veya çokluğunu bir anlamda güvenlik bariyerleri olarak da düşünebiliriz. Onlar, yasadan faydalanılmasına önceden izin verilmeyecekler (itaate yanaşmayanalar veya istendiği şekilde itaat etmeyenler) için karşılarına çıkartılacak bir suni engeller seti olarak işlev görür.

İktidar, iktisadi anlamda gücünü büyük ölçüde kaynakların kime veya kimlere aktarılacağına karar vermede gösterir. Gelişme/büyüme, kalkınma ve verimlilik gibi hususlar, bu ilişki ağının bir dolayımı olarak görünür. Eğer gerçekten mevcut kültürel zemin çerçevesinde bir iş yapmaya kalkılırsa, iktidarın payına yerinde saymaktan başka bir șey düşmeyecektir. Kaynak israfi kendini sürekli tekrarlayacaktır. Bunun bir nedeni kolektivist kültürdeki zaman ve zemine göre șekillenen bağlamsal ahlak olduğu kadar, diğer nedeni de Türklerdeki güç mesafesinin ${ }^{47}$ yüksekliğidir.

47 Hofstede'in kullandı̆̆ı ayrımlardan bir diğeri ise "güç mesafesi"dir. Güç mesafesi (power distance); Bir toplumdaki farklı sosyo-ekonomik seviyelerdeki bireylerin, aralarındaki ayrımı ne kadar önemsediklerini ve onu kabullenmelerini anlamamıza yardımcı olur. Sosyo-ekonomik farkı dikkate alma anlamında ast ve üstler arasındaki ayrımın yüksek olduğu toplumlarda astlar üstleriyle mücadeleye girişemezler. Üstlerden daima bir yönlendirme beklentisinde olunur. Mesafenin düşük olduğu Batı gibi toplumlarda ise bireyler toplum içinde eşit bir güce sahiptir. Türkiye'nin de içinde olduğu yüksek güç mesafeli ülkelerde: Eşitsizlikler normal görülür, hiyerarşi normal bir ihtiyaç olarak görülür, üstlere erişilmez, sosyo-ekonomik yönden güçlü olanların ayrıcalıklara sahip olması doğal karşılanır, değişimler darbe veya devrimle olur ve çocuklara söz dinlemeleri (itaat) öğretilir: Hofstede, Cultures and Organizations: Software of the Mind, 53-88. Buradan hareketle, M. Bilgin Saydam'ın Deli Dumrul'un Bilinci'nde savunduğu bağlamda konu, bu yazının amaçları dişında olsa bile, çocuğun söz dinlemesini anne güdümünde (dişil bilinç/bilinçdışı) olmaklığı, babanın (tin-eril bilinç) yasa koyuculuğuna/yasaklayıcılığına doğru çocuğun yolculuğunda babanın 
Güç mesafesinin dildeki karşılı̆̆l, siz veya sizlerdir.48 Karşıdaki kişi, sosyal ve ekonomik olarak diğer kişiden yüksekse, ona karşı hitap otomatikman/kendiliğinden "sen"den "siz/sizler"e dönüşür. İlk tanışmalarda önce memleketin sorulması tekilsel kültürden, sonra da yapılan işin/meşguliyetin sorulması ise yüksek güç mesafesinden kaynaklanır. Hitap ifadesindeki kararsızlık bir an evvel aşılarak utanca düşülmemelidir. Her "siz/sizler" deyiş veya demek zorunda kalış, karşı taraf nezdindeki altsal konumu kabulleniş veya utancı tekrar tekrar hatırlayıştır: Herkes yerini bilecek. Bu da, toplumda kişiler arası iletişimi olabildiği kadar en alt seviyede tutmakla veya altsal oluşu içselleştirmekle aşılabilir. İletişimsizlik ise kaynak israfına ve maliyet artışına neden olmaya açıklığı içeriyor.

Yabancıyla iletişimde ilk elden memleketin sorulması, Türklerin akrabalık bağı dışında bir ilișki kurma zorluğuna işaret ediyor. Zaten her hâlükârda sokaktaki yabancıya ilk soruş, erkekse yaşına göre abi, kardeş, amca, dayı; kadınsa yine yaşına göre abla, bacl, teyze, anne vs. şeklinde gerçekleşiyor. Yabancıyla kısa karşılaşma dışında bir iletişim veya alış-veriş olacaksa, diyalogun önemli bir kısmı mümkün olduğunca ortak tanıdıklar aranarak geçiyor. Aksi takdirde karşıdaki -akraba olmadığına göreyabancının, kişiyi, grup-dışından olduğu için her türlü kandırma hakkına sahip olduğu varsayılıyor. Çünkü ahlak, sadece aile içine

(toplumsal) yasasını içselleștirmediğini, çünkü anneden (doğa/dişil bilinç/bilinçdışı) çıkamadığını da ima eder gibi görünüyor. Babanın yasasının içselleştirilememesini, Türklerde kuralların otoritesinden çok, otoritenin kurallarının daha güçlü olması gerçekliğinden örnekleyebiliriz. Çocuğu besleyip büyütme ve bakma sorumluluğunun annede kabul edilmesi, Türkler için devlet devlet baba olarak anılsa da, daha çok devletin devlet ana olarak düşünülmesini gerektiriyor. Kemal Tahir ve Cengiz Aytmatov'un eşsiz eserleri bu bağlamda yeniden düşünülebilir: Kemal Tahir, Devlet Ana (İstanbul: İthaki, 2018) ve Cengiz Aytmatov, Toprak Ana, çev. Refik Özdek (İstanbul: Ötüken Neşriyat, 2018). Anne figürü bu bağlamda sadakata, baba ise liyakata eşlik ediyor diyebiliriz. Buradan da baktığımızda Türk toplumunun hâlen sadakat esaslı bir siyaset ve hatta ticaret ve iktisadiyat izlediği bile öne sürülebilir.

${ }^{48}$ Siz/sizler, üç farklı konum için kullanılıyor. Birincisi, karşıdaki çokluğa karşı; ikincisi, yabancıya hitapta ve üçüncüsü de üst konumlardakilere karşı. Burada üst konumdakilere karşı kullanıldığı biçimiyle ele alıyorum. 
karşı etkisini gösteriyor. Aile dışından yabancılarla ortak iş yapmanın, şirket kurmanın zorluğu da kendiliğinden ortaya çıkmış oluyor.

Son zamanlarda bu yönde olumlu bir değişim -aile dıșı ortaklıklar- hissedilse de bunun Türkiye'nin büyüme oranıyla kıyaslanamayacak derecede önemsiz olduğu aşikârdır. Türkiye'nin önde gelen holdinglerden biri olan Sabancı Holding Yönetim Kurulu Başkanı Güler Sabancı'nın bu konuda verdiği bilgi de analizimizi teyit etmektedir: "Türkiye'deki işletmelerin yüzde 95'ini aile şirketleri oluşturuyor. Türkiye'de aile şirketlerinin ortalama ömrü 25 yll. Bu aile şirketlerinin sadece yüzde 30'u ikinci kuşağa, yüzde 12'si üçüncü kuşağa geçebiliyor. Dördüncü kuşağa geçebilenlerin oranı ise yüzde 3 'te kalıyor. Cumhuriyet öncesi dönemde kurulmuş ve bugün hâlâ devam eden işletme sayısı sadece $69^{\prime \prime} .49$

Türkçe'deki yabancı kelimelerin ünlü uyumuna uymasını beklemenin, onları bir anlamda boşlukta, değer yargılarının dışında bırakmakla eș anlama geldiği ifade edilebilir. 0 kelimeler, cümlede yerini/haddini bildiği, yabancılığı/ayrıksılığı herkes tarafından kabul edildiği müddetçe, hiçbir sorun çlkarmayacaklardır. Bu durumda o kelimeler, Türkçe'nin her türlü seslendirme yetkisine açık olmayl, himayesini kabul etmeyi ve hatta bazen ünlü uyumu bağlamında içerilmeyi bile göze alabilirler: Yuro/Avro, bazen/bazan, itibariyle/itibarıyla, makine/makina, üstad/usta, halife/kalfa, çerağ/çıra-k, vs.

Bir ağacı veya cümleyi güçlü kılan nasıl onun sahip olduğu köklerse, Türklerdeki köken kaygısı da (kimlerdensin, sen benim kim olduğumu biliyor musun?) o denli baskın ve güçlü görünüyor. Kişiye yapılan eşit muamele, daha doğrusu kuralın uygulanması, kökeninin/ailesinin güçlü olduğunu düşünen kişiler tarafından rahatlıkla hakaret olarak değerlendirilebiliyor. Egemen iktisadi anlayış çerçevesinde mülkiyet bugün gücün tek kökeni/kaynağı gibi görünse de, baskın kültürün etkisinden dolayı retorik

49 Hürriyet Gazetesi, http://www.hurriyet.com.tr/ekonomi/turkiyedekiisletmelerin-yuzde-95i-aile-sirketi-40599291 (29.05.2018). 
üstünlüğü ve dini otorite gibi başka araçların da toplumsal yapıyı etkileyebileceğini ve şekillendirebileceğini söyleyebiliriz. 'Sen benim kim olduğumu biliyor musun?’da olduğu gibi kökene ilişkin imayl/vurguyu mülkiyet üzerinden değil -ki onu inkâr etmiyoruz-, toplumda içkin olan informel sosyal kontrol araçları -itibar/şeref kültürü- çerçevesinde değerlendirmek daha doğru bir yol gibi gözüküyor.

İtibar/şeref kültürü ise başlı başına evrensel eşitlik kavramına karşıt bir kültür konumunda. Bu anlamda bireylerarası eşitlik, yaratılan/kazanılan muteber/itibarlı konum dışında kalanların payına düşen oluyor. Stadyumlardan örnek verirsek, Şeref Tribünü dışında kalan tüm seyircilerin eşitliği ölçüsünde bir eşitliktir bu. Ancak şeref/itibara geçişin de aynı zamanda çok kolay olduğu ve bunun her an olabileceği herkes tarafından kabul gören bir düşünce olduğu için şerefliler (eşraf, ayan vs.) toplumda eşitsizliği bozduğu anlamıyla yadırganmamaktadır. ${ }^{50}$ Çünkü, hemen herkeste siranın her an kendisine gelebilme ihtimali canlı tutulur. İhtimal, gerçekleşme derecesini merkeze/köksese/iktidara yakınlık ölçüsünde arttırır. Toplumda neredeyse herkes sırasını beklemektedir. Sıranın her an herkese gelebileceği, bir kuşun başa konma ihtimali kadar yakındır. Bu kuş, talih kuşudur: Belki de sıra sizde!

Türkiye'nin en zengin ailelerinden olan Koç grubunun en çok bilinen beyaz eşya markası olan Arçelik için Anadolu'daki esnafların bayiliğe kabul edilme nedenlerinin en başında, onların sadece gelir ve zenginlikleri değil, daha da önemli görülen, çevrelerinde muteber, sözüne güvenilir kişiler olması geliyordu. ${ }^{51}$

\footnotetext{
50 Toplum tarafından içselleştirildiği için yadırganmasa da, Tanzimat döneminde devlet açısından eşrafa bakışta da bir değişiklik göze çarpmaktadır. 18. yüzyıl sonu ve 19. yüzyıl başında Osmanlı'nın ekonomik ve askeri bakımdan iyice zayıfladığının hemen herkes tarafından fark edilmesiyle eşrafın bir adım daha öne çlkma isteğini önce sineye çeken ve fakat Tanzimat gibi yeniden toparlanma arzusunun gösterildiği ilk fırsatta devlet, eşrafın de facto öne çıkışını hemen engelleyecektir. Ayrıntılı bilgi için bkz. Metin Heper, Türkiye'de Devlet Geleneği, çev. Nalan Soyarık (İstanbul: Doğu Batı Yayınları, 2015), 77.

51 Ayșe Buğra, Devlet-Piyasa Karşıtlığının Ötesinde, çev. Bahadır Sina Şener (İstanbul: İletișim, 2010), 81.
} 
Ekonominin siyasetten özerkleşme anlamında ayrışmadığı Türkiye'nin de içinde bulunduğu kültürlerde ekonominin siyaseti etkileme gücünden çok, siyasetin ekonomiyi belirleme gücünden bahsedebiliriz. Bu anlamda ekonomik zenginlik her zaman itibarı getirmese de, itibar, zenginliği büyük ölçüde getirecek ve el'ân getirmeye devam etmektedir.

Türkiye'de/Türklerde bireylerin davranışlarını yönlendirmede en güçlü yapı olan kolektivistik kültür -ki devletle iç içe geçmiş ve birbirini destekler-52 gereği aile (ailenin uzayan ve genişleyen her boyutu) ve onu da yönlendiren itibar/şeref anlayıșıdır diyebiliriz. Devleti bu anlamda aileden ayrı değil, yine kolektivist kültür gereği büyük aile olarak kimi zaman baba, kimi zaman da ailenin anası olarak çocuklarının üzerinde titrer görüyoruz. Mevcut Anayasa'nın başlangıç kısımlarında "Bu Anayasa, ...dünya milletleri ailesinin eşit haklara sahip şerefli bir üyesi olarak, ... TÜRK MİLLETİ TARAFINDAN, demokrasiye âşık Türk evlatlarının vatan ve millet sevgisine emanet ve tevdi olunur."53 denmektedir.

Toplumdaki güç mesafesinin yüksekliğinden dolayı üst konumda olan, bütüncül (kolektivistik) kültür gereği her bakımdan üst konumda algılanıyor. Kendini üst konumda gören iktidar da, karşısındakini her bakımdan alt konumda görüyor. Bu da, siyasetin normale dönmesinin, çatışmadan uzaklaşmasının önündeki en büyük engel oluyor. Çoğu zaman basit gibi görünen bir sorun, hiç beklenmedik bir (kavga, ölüm, çoğu zaman "şerefsiz"likle suçlama) şekilde sonuçlanabiliyor. Siyaseten muhalefette olmak, iktidar açısından her bakımdan düşüklüğü, ahlaksızlığı, geriliği, zihnî veya ekonomik beceriksizliği; iktidarda olmak da bunun tersini temsil ediyor. Kökleri Orta Asya'ya kadar giden han-ı yağmanın ${ }^{54}$ (potlaç, armağan, ziyafet, toy, vs.) boya/aileye kazandıracağı şeref/itibar, onların toplumda her bakımdan üstün görülmesine kadar

52 Önderman, Türkiye'de Devlet Sosyal Kontrol ve Öznellik, 27.

53 Türkiye Cumhuriyeti Anayasası, Kanun No: 2709, Resmî Gazete Tarih: 9.11.1982, Sayı: 17863 (Mükerrer), “Başlangıç” Kısmı.

${ }^{54}$ Ziya Gökalp, Türk Uygarlı̆̆ı Tarihi, haz. Yusuf Çotuksöken (İstanbul: İnkilâp Kitabevi, 1991), 52. 
vardırılıyor. Üstünlük bağlamında şeref/itibarın da ancak iktidarı ele geçirmekle kazanılacağı ve oradan ayrılmak zorunda kalınca kaybedileceği, toplumda genellikle kabul gören bir düşünce. Siyasette neredeyse hiçbir şekilde istifanın görülmemesi, başarısızlığın kabullenilmemesi, her yönden düşüklüğü kabul etmekle eş anlama geleceği korkusundan kaynaklanıyor.

Söz konusu kültürde (bütüncül) hiçbir şey kendi başına bir anlam ifade etmiyor. Dahası, tek başına bir değer de ifade etmiyor. Herkes veya her şey gücünü veya değerini içinde bulunduğu bütün şey/özne/kültürden alıyor veya anlamı bir başka şey ile tamamlanıyor. Tıpkı kelime, anlamını cümlenin veya metnin genel anlam-akışından almasında olduğu gibi. İktisat da bu bağlamın ancak ve ancak bir unsuru olarak anlamını/değerini kazanabiliyor veya değer yaratabiliyor.

Türkiye'de devlet tümgüçlü (her bakımdan üst konumda) bir kurum olarak algılanıyor. Tümgüçlü olarak düşünülen devlet, kişi veya grupların bir kısmı tarafından idealleştirilirken, diğer bir kısmı tarafından da hemen her şeyin sorumlusu olarak görülüyor. ${ }^{55}$ Devletin iyi veya kötü hemen her şeyi yapabilme gücüne sahip olduğuna dair güçlü algı, pek çok konuda olduğu gibi iş ve iktisat alanında da onun bütün sorunları çözebileceğine dair inanca kaynaklık teşkil ediyor. Devletin taşıdığı veya taşıdığı varsayıldığı bu güçlü imajın dayanağının zayıflaması durumunda ise toplum kendisini bir boşlukta hissetmeye başlıyor. Bireyler, kendilerini küçük veya büyük bir ailenin parçası veya onun iş-teşi (ailenin gücü ve desteğiyle birlikte eyleyici) olarak, ailelerini de bir anlam odă̆ı olarak görüyorlar. Bireyler, bir anlam odağı olarak üstünde veya çevresinde bulunduğu ailelerinin (toplum, millet, din, etnisite, ideoloji, akraba çevresi) sayesinde veya birlikteliğinde ne yapacaksa yapabilir oluyorlar. Bireyin bir iş yapabilmesi, işi tek başına yapabilme gücüne veya bilgi-deneyime sahip olmasından dolayı değil, ailesine sadık olduğundan/olacağından dolayı, çokluğu/grubu teyit ettiği ölçüde işe kavuşabiliyor. Bu anlamda grubun bir parçası/uzvu olan bireyin, grubundan veya grubu

55 Önderman, Türkiye'de Devlet Sosyal Kontrol ve Öznellik, 27. 
sayesinde iş alması için sadakati/itaatini ispatlaması, büyük ölçüde sırasını itirazsızca beklemesi ile mümkün oluyor. Bu bekleyiş, onun tecrübeli olmasını sağlamaya büyük ölçüde yetecektir.

Dayın varsa işler/gerisi kolaydır. Burada dayı, kandaş ailenin iş-teşliğini tamlayan hükmündedir. Kandaş aile yetmediğinde veya olmadığında da dini/ideolojik/etnik aile yardıma gelmektedir: Hamili kart yakınımdır. Ancak bu kartları almak için de kişinin çok bilgili/liyakatli olmasından ziyade, söz konusu ailesine sadık olması gerekecektir. Sadakat, bağlamına göre uyumun da eşdeğeri olarak görülebilir. Örneğin grup/ailedeki bir kişi için; özünde iyi ama uyumsuz bir arkadaş denmesi, büyük ölçüde o kişinin işlerinde başarılı olsa da, daha önemli bir özellik olan sadakatinde sorun olduğu, armağan dünyası/ekonomisinin gereklerini yerine getirmediği ima edilmiş olur. Aile bu ikramı (güvenceyi/kartı) evladına verirken, ondan da fazlasıyla geri dönüşü (itaat, sadakat/düzenin beklemektedir. devamı/statükonun

korunmasinı)

Jenny B. White'ın, İstanbul'un \% 60 nüfusunu temsil ettiğini söylediği (gecekondu bölgeleri ve işçi nüfusu ağırlıklı) bölgelerde yaptığı iki yıl süren araştırmasında vardığı sonuç, bireyin kimliğinin birincil alanının toplumsal grup olduğu yönündedir. $\mathrm{Bu}$ grupların en temeli aile iken, sırasıyla komşuluk, din veya millet de olabiliyor. White'ın, Duben'in bir çalışmasından (1982) aktardığı bilgi de, hızlı kentleşmeye rağmen geleneksel Türk ailesi içindeki duygusal ve ekonomik bağımlılığın azalmadığı yönündedir. ${ }^{56}$

Türk tarihi boyunca anca beraber kanca beraber olarak da düşünülebilecek grubun bireye önceliği -her şey grubun çıkarları için- ve iş-teşlik, Selçuklu ve Osmanlı dönemi ahilik teşkilatındaki usta-kalfa-çırak (üstad-halife-çerağ) hiyerarşik birlikteliğinde olduğu gibi, daha naif mesleklerden olan hat veya klasik Osmanlı müzik geleneği çevresinde de durum (meşk) bundan farklı değildir.

56 Jenny B. White, Para ile Akraba, çev. Aksu Bora (İstanbul: İletişim, 2015), 27; Alan Duben, "The Significance of Family and Kindship in Urban Turkey," Sex Roles, Family and Community in Turkey içinde, der. Çiğdem Kağıtçıbaşı (Bloomington: Indiana University Turkish Studies, 1982), 73-100. 
Fakat burada asıl vurgulamak istediğim, mesleki hiyerarşi veya birliktelikten ziyade, çırağın mesleğe alınması veya kabulü, iktisadi anlamda işe kabul edilmenin ötesinde bir anlam taşımasıdır. İktisadi ilke, kabulün pek çok nedeninden biridir sadece. Her yönden ustasına teslim edilen veya ustası tarafından kabul edilen çırak sadece mesleği öğrensin diye değil, başta ahlaki yön olmak üzere olgun bir insan (insan-ı kâmil) olsun diye kabul edilir. Sanatsal faaliyetinin büyüsü, maddi faydadan ziyade mesleki gurur, şeref veya itibarıdır. ${ }^{57}$

Her mesleki hane bir aile ocağı gibi anlam yüklüdür. Mesleki bilgi deneyime içkindir, ustadan çırağa zaman içinde ustanın istediği şekilde sözlü kültür ${ }^{58}$ çerçevesinde aktarılır. Usta veya çırağın işin içinde olması, aynı zamanda bir tarikatta oldukları anlamına da gelecektir. Çırak işinde özerk değildir. İșini terk etmesi kandaş ailesinin, işinde ilerlemesi ustasının, işinde yanlış yapması halinde de hepsi birlikte meslek şeyhinin kontrol ve gözetimine tabidir. Gerek imalat ve hizmet dalında örgütlenen ahilikte, gerekse hat ve müzik gibi alanlarda çıraklar işlerini kalfa veya ustasından bağımsız olarak öğrenemiyorlardı. Bu şu demek; çırağa işi öğretecek kişiden başka bir nesne, örneğin iş yönergesi, iş rehberi veya notadan yoksunluk. Klasik Osmanlı müziği için söylersek, XX. yüzyılda Alaaddin Yavaşça'ya (d.1926-...) gelinceye kadar müzik, ustadan "geçilerek" öğrenilebilen bir iști. Usta ile çırak meşk ederek, eseri birlikte "geçiyor"lard1. ${ }^{59}$ Usta Yavaşça, hem nota ile hem de meşkin zevkini tadarak öğrencilerini/çıraklarını yetiştirmekle bir geçiş dönemi figürünü örnekliyor.

2000'li yılların başında kamuda bile pek çok kurumda (şimdi Kalkınma Bakanlığı olan bir zamanların DPT'si, vergi daireleri vs. hariç) iş yönergesi bulunmuyordu. Acemi/stajyer/aday memur için işler, büyük ölçüde, bir bilenin, deneyimli memur veya şefin eline bakılarak öğreniliyordu. Oysa Batı'da, on asır önce veya yaklaşık 1000 yıl önce, XI. yüzyılda Guido d'Arezzo tarafından geliștirilen

\footnotetext{
57 Ülgener, İktisadi Çözülmenin Ahlak ve Zihniyet Dünyası, 103.

58 Walter J. Ong, Sözlü ve Yazılı Kültür, çev. S. P. Banon (İstanbul: Metis, 2014).

59 Güneş Ayas, Müzik Sosyolojisi: Sorunlar-Yaklaşımlar-Tartışmalar (İstanbul: Doğu Kitabevi, 2015), 346.
} 
notasyon, usta ile çırak arasındaki doğrudan teması zorunluluktan çıkararak, eserin çırak veya öğrenci tarafından tek başına çalınabilmesinin yolunu açmıştı. ${ }^{60} \mathrm{Bu}$ anlamda Batı ile Türkler arasındaki mesafenin maddi kazanımlardan ziyade, zihnin yapısını da şekillendiren, eşyanın veya davranışların kişinin kişiliğinden ayrı düşünülemiyor olmasıdır. Eşya veya davranışlar, kişilikten ayrı düşünülemediği için onu kendisinin bir nesnesi olarak görememesine, göremediği için inceleyememesine ve kritik edememesine neden olmaktadır.

Türkiye'de eleştirinin gelişememesinin nedenlerinin başında, kişinin nesnesi hükmündeki eserinin, kişilikten ayrılmış bir parça olarak değil, kişiliğin bir uzvu, organı olarak görülmesi gelmektedir. Esere ilişkin eleştiri, olumsuz yanlar içerdiğinde durum, tamiri neredeyse imkânsız yaralar açarak, kişiliğe yapılmış hakaret olarak algllanıyor ve bu da kişiliğin örselenmesine neden oluyor. Eleştiriyi yapan kişinin payına ise kara kaplı deftere kaydolunarak ömür boyunca kaza oklarının açık hedefi olmak düşüyor. Böyle bir ortamda güvensizlik, her an tetikte olma, kişinin başka bir işe odaklanmasının önündeki engellerden biri olmaya neden oluyor. Eleştirinin göze alınmaması ve tercih edilmemesi sonucunda da vasatın egemenliğine ${ }^{61}$ kapı açılmış oluyor.

60 Ayas, Müzik Sosyolojisi: Sorunlar-Yaklaşımlar-Tartışmalar, 347. Öğrencinin eseri elinde tutabilmesi, esere tekrar tekrar bakabilmesi, istediği yeri değiștirebilme imkânına sahip olması, eserin ustadan ayrışarak nesne modunda algılanmasına ve ona sahip olabilmesinin de önünü açarak bireyin hem özne, hem de mülkiyet kavramının gelişmesi veya arzusunun doğması açısından düşünülmeye değer. Diğer bir husus da, bütünsel/küllî bir parça olan eserin notalarla matematiksel kesinlikte parçalara ayrılması, Batı'nın erken rasyonelleşme (ölçü/oran/birim/metric-leme) örneği olarak da okunabileceğini düşündürüyor.

61 Ahmet Hamdi Tanpınar, Sahnenin Dışındakiler (İstanbul: Dergâh Yayınları, 1999), 56'da, Osmanlı son döneminde söz konusu vasatın egemenliğini tecrübe kavramının kullanılışı üzerinden şu sözlerle ifade eder: "İsabetli tek bir hareket veya fikri olmadığını, her gün hâdiselerin yumruğuyla yeni baștan bir daha öğrenen bir toplulukta, bu tecrübe kelimesinden ne kastedilirdi, bunu çok sonra anladım. Meğer bu tecrübe denen şey, bizim kitaplarda öğrendiğimiz mânâsından çok ayrı bir yerde kullanılırmış. Onun asıl mânâsı dünya işlerinde bir nevi sinizmi benimsemek, onun için de dört tarafını kollayarak, kimseyi 
Diğer taraftan eleştirinin kolayca lince dönüșen bir yanı da var. Eleştirilecek eser eleștiriye veya davranış yargılanmaya, büyük ölçüde kendilerinden dolayı veya kendisi olmaklığı dolayısıyla değil, eserin veya davranışın kime(kökene) ait olduğu dolayısıyla önem taşıyor. $\mathrm{Bu}$, toplumda informel (ailenin, grubun/cemaatin normu vs.) mekanizmaların formel (yasa vb.) mekanizmalardan daha güçlü olduğu anlamına geliyor. Yazdığınız bir yazı/kitap veya iktisadi faaliyette bulunulduğu sıradaki bir mali eylem, şeref sahibi/muktedir bir yere yakın olduğunuz esnada sorun oluşturmazken, en büyük statüyü sağlayan iktidar el değiştirdiğinde veya muhalefetin yanına geçildiğinde veya kendi grubunuzu eleștirdiğinizde aynı yazı veya mali işlem, her yönden incelenecek, işletmenizde pek çok mali sorun/eksik bulunacak veya buldurulacaktır.

$\mathrm{Bu}$ da, kuralların otoritesinden çok, otoriterin kurallarının topluma egemen olduğunu gösteriyor. Böyle bir kültürde bireyler veya iş-letmeler, rasyoyu (ölçü, hesap, oran vb.), verimliliği, liyakatı değil, köke/şerefe sadakati daha makul bulacaklardır. Statüyü veren, toplumdaki en büyük veren el olarak devletin kendisi oluyor. Devlet de, devlet olmaklığını verdiği müddetçe hissediyor. Şerefe/statüye yakın olduğu ölçüsünde değerleneceğini düşünen toplumda, iktisadi anlam da dâhil olmak üzere her alanda hiçbir iş, gücünü veya önemini kendinden alamıyor. Kendinde iş, kendinde şey ve kendinde birey söz konusu olamıor. Hatta kendinde iktidar bile yok denebilir. Tek başına bir suç işlense dahi, arkasında örgütlü/başka/kök bir yapının olduğuna dair toplumda neredeyse kesinlik derecesinde köklü bir inanç göze çarpıyor. Bu durum, hiç kimsenin, tek başına, her ne olursa olsun bir işi yapamayacağına

rahatsız etmeden, büyüğü kuşkulandırmadan, küçüğü sabrın son haddine getirmeden rahatça yahut gailesizce yaşamak, hayat yolunda her vesileden istifade ederek ilerlemek, ev, köşk, apartman, han; esham sahibi olmak imiş. İşte ben bu merhaleye ermek için lazım gelen bekleme devrinde idim. Bunun adı okumaktı. Hakikatte ise sadece vaktini beklemekti. Çünkü gittiğim mektepte hemen hemen hiçbir şey öğrenmiyordum. Fakat gidiyordum. Aynı fabrikadan çıkmış iki tuğla kadar birbirine benzeyen hocalar... hepsi bana... geçmeye behemehal mecbur olduğum bir makinenin dişleri gibi geliyordu." 
dair düşünceden kök alıyor. Türklerin iş zihniyeti olgusunun ise bu bağlamın dışında seyretmesi olası gözükmüyor.

\section{Türklerin iş zihniyeti}

İş zihniyetine egemen olan düşünce, Türklerin işleri bir-likte yapma arzusudur denebilir. Birliktelikler, büyük ölçüde ve sırasıyla aile, etnisite-hemșerilik, din, millet, ülke ve bölge temelinde tamamlanma eğilimindedir. Ancak bu birliktelikler, yukarıda anılan kültürün etkileri çerçevesinde uzun süre devam edememektedir. Dünden bugüne ilerleyen tarih boyunca baskın kültürün etkisi azalsa da, varlığı büyük ölçüde devam etmektedir. Aşağıda maddeler halinde, Türklerin iş zihniyetinde etkisi olduğu düşünülen nedenler ele alınacaktır.

\section{1. Belirsizlik}

İşlerini kervan yolda düzülür modunda algllayan Türkler, işe başlarken ayrıntılar, ayrımlar ve sorumlulukların sınırları konusunda konuşmayı son derece rahatsız edici bulmaktalar. Bu, hiçbir zaman sorumlulukların belirtilmediği anlamında yorumlanmamalıdır. Söz konusu sorumluluklar usulen belirtilir. Fakat genellikle değişmez kural, herkes her şeyden sorumludur ilkesinin geçerliliğidir.

Örneğin bu durum, Türk bürokrasisinin harcama anayasası gibi görülen kanundaki sorumluluk anlayışına baktığımızda daha iyi anlaşllabilir. Bilindiği üzere Türkiye Cumhuriyeti devletinin harcama mevzuatına temel teşkil eden ve bugün de genel yönetim kapsamındaki kamu idarelerinin tamamında yürürlükte olan 5018 sayılı Kamu Mali Yönetimi ve Kontrol Kanunu,621927'de uygulanmaya başlayan 1050 sayılı Muhasebei Umumiye Kanunu'nun ${ }^{63}$ yerine getirilmişti. Gerek dili, gerek güncellenme zorunluluğu ve gerekse AB yasalarına uyum çerçevesinde 1050

${ }^{62}$ Kamu Mali Yönetimi ve Kontrol Kanunu, Kanun No: 5018, Resmî Gazete Tarih: 24.12.2003, Sayı: 25326.

${ }^{63}$ Muhasebei Umumiye Kanunu, Kanun No: 1050, Resmî Gazete Tarih: 9.6.1927, Sayı: 606. 
sayılı kanunun yerine 5018 sayılı kanunun getirilmesi, bürokrasideki sorumluluğun birlikteliği anlayışında bir değişiklik yaratmamıștı. 79 yll yürürlükte olan Muhasebei Umumiye Kanunu'nun 22. maddesi bunu açlkça ortaya koyar: “A): ...[I]]ta amiri ve tahakkuk memuru yukarıdaki hususlardan birlikte sorumlu olurlar." Yine maddenin devamında "B) a- Bir giderin yapılmasına gerek gösteren görevliler, giderin gerçek gereksinme karşılığı olmasından tahakkuk memuru ile birlikte... sorumludurlar." diyerek birlikteliğe gönderme yapmış oluyor. Aynı kanunun yerine 2006'de yürürlüğe giren Kamu Mali Yönetimi ve Kontrol Kanunu ise harcamanın sorumluluğunu harcama yetkilisine verse de (mad. 32), "Gerçekleştirme görevlileri, bu Kanun çerçevesinde yapmaları gereken iş ve işlemlerden sorumludurlar." (mad. 33) diyerek, sorumluluğu bir şekilde daha da genişletmiştir. Genişletme, genel yönetim kapsamındaki tüm kurumlarda yapılan harcama için düzenlenen "Ödeme Emri Belgesi" adlı belgede imzası yer alan ve imzası olan herkesi kapsaması anlamında sayısı sınırsız/belirsiz gerçekleştirme görevlilerince harcama yetkilisinin sorumluluğunu "birliktelik" içinde vurgular.

Sorumluluğun net belirlen(e)memesi, suçun failini örtme anlamında da işlevseldir. Kamu ihalelerindeki onca yolsuzluk imasına/haberine rağmen sorumluların bulunamaması, bulunduğunda da herkesin suçlu görülme eğilimi, anca beraber kanca beraber anlayışının baskınlığı olarak değerlendirilebilir. Fakat belirsizlik, sadece kamu kaynağ veya mevzuat olarak değil, devletin iktisat politikalarında seçtiği yollar bakımından da fark edilir. Ayşe Buğra, Devlet ve İşadamları'nda, işadamlarının en çok yakındığı konuların başında devletin uyguladığı veya uygulayacağı iktisat politikalarının belirsizliği olduğunu vurgulamaktadır.64 Bunun sadece 50’liler için değil, cumhuriyetli yılların pek çok dönemi için de geçerli olduğu söylenebilir. ${ }^{65}$

\footnotetext{
${ }^{64}$ Ayşe Buğra, Devlet ve İşadamları, çev. Fikret Adaman (İstanbul: İletişim, 2016), 188.

65 Buğra, Devlet ve İşadamları, 205.
} 
Mevzuattaki sorumluluklar bağlamında birlikteliğe havale edilerek vurgulanan belirsizlik, diğer alanlar için de aksine aşırı ayrıntıcıdır. Her sorun için yasa yapma düşüncesi, yasaların bütün sorunları çözeceğine olan inanç olarak ifade edilebilecek legalizm, aynı zamanda "mümkün olduğu kadar çok şeyi bilinebilir, tahmin edilebilir veya öngörülebilir kılma isteğine yol açan paranoid düşüncenin [de] bir görünümüdür."66 Ancak bunun hukuk devleti ile ilgisinin olmadığının belirtilmesi gerekir. "Zira hukuk devleti bir değerler sistemine dayanırken, kırtasiyecilik bir kontrol aracıdır."67

\section{2. Her türlü birikimin kümülatifliği içermemesi}

İçinde bulunulan baskın kolektivist kültür gereği Türkiye'de kişiler, kişilik veya benlik, sosyal ilişkiler veya sosyal rollerce tanımlanmıştır. Kültürdeki baskın karşılıklı bağımlı benlik anlayışı da toplumsal bağlama göre yapısını değiștirmektedir. ${ }^{68}$ Bağlamın ana belirleyicisi ilk olarak aile olsa da, duruma göre statü veren en büyük güç olarak devlet öne çıkmaktadır. Aile ile devlet arasındaki her istasyonun kendine göre farklı bir dili, raconu, ahlakı ve ilişki tarzı vardır. Her istasyon değişikliğinde kişi, aynı ilişki tarzını sürdürmez. Tarzını, bağlama göre değiştirmesi gerekecektir. Kişi, her istasyon değişikliğinde kazandığı tecrübeyi bir sonrakinde aynen kullanamaz. Kişinin konumu, makamı değiştiği için her istasyonun kişiden beklentisi farklı olacaktır. Her konum değişikliği, farklı bir ahlaka uyum sağlaması anlamına gelecektir. $\mathrm{Bu}$ da, her istasyonda kilometrenin sıfirlanması demektir.

Her iktidar döneminde öne çıkıp, büyüyüp ve sonraki iktidarlar dönemine sıfırlanarak giren ve sıfırlanma olmasa da eski gücünü büyük ölçüde yitirerek giren işletmeler, hiç de az değildir. Kuruluşu 100 yaşını geçen işletmelerin çok az sayıda olması, olanların da çoğunun bugün önemli bir büyüklükte olmaması, büyük sanayici ve ticaret işletmelerinin kurucuları arasında eski

\footnotetext{
66 Önderman, Türkiye'de Paranoid Ethos, 206.

67 Önderman, Türkiye'de Paranoid Ethos, 206.

68 Önderman, Türkiye'de Devlet Sosyal Kontrol ve Öznellik, 29.
} 
toprak sahiplerine rastlanmaması ${ }^{69}$ sürekliliğin sağlanamaması ${ }^{70}$ ve kümülatif bir büyüme içinde olmaması bağlamında anılmaya değer hususlardandır.

\section{3. Patronajın bütünsel yapısı}

Toplumda hâkim olan bütüncül (holistik, kolektivistik) kültür gereği patron, işletmesindeki çalışanların hayatının her boyutuyla ilgilenme gereği duyar. ${ }^{71}$ Yüksek güç mesafesi gereği iktidarın iyi olarak değerlendirilmek durumunda olan yapısı, işçilerinin de ücret ve haklar bakımından durumlarının iyi olmasını, benzerlerine göre haklarının yüksekte görülmesine neden olacak şekilde düzenlenmesinin önünü açar. Bu özellik, yabancı ortaklı sermaye şirketlerine dönüştükçe, çalışana karşı yabancılık (sırayla aile, etnisite-hemşerilik, din, ideoloji, millet, ülke ve bölge) arttıkça, daha doğrusu informel sosyal kontrol nesnelerine -örneğin utançkarşı daha soğukkanlı davranılarak veya davranıldığı ölçüde rasyonelleşecektir. Rasyonelleşme, yabancılığa yaklaşma ölçüsünde kendini aktüel kılacaktır da denebilir. Bunun da, sosyal kontrolün informel sosyal kontrolden daha güçlü olmasıyla yürürlüğe girdiği açıktır. Duyguların sosyal çevrenin yaptırımlarına karşı duyarlılığı azaldıkça rasyonel eğilimlerin güçlenmesi, duygusallık ile rasyonelliğin birbirine zıt yönlerde konumlandığına işaret ediyor. $\mathrm{Bu}$ bağlamda Türklerin duygusal olduğu düşünüldüğünde, rasyonellikle arasındaki mesafesinin büyüklüğü de ortaya çıkmış oluyor.

Patronajı bu anlamda hatır ekonomisi olarak da görebiliriz. Duygusal düzeyde de üretici olan sosyal kontrol, Türkiye'de özellikle sadakat, hatır (borçluluk), aidiyet ve utanç gibi duygularda yoğunlaşmaktadır.72 Armağan ekonomisinin bir görünümü olan

\footnotetext{
${ }^{69}$ Buğra, Devlet ve İşadamları, 42.

70 Modernlik bağlamında "kültürel süreklilik" kavramı üzerinden konunun benzer tartışması için bkz. Besim F. Dellaloğlu, Zamanın İçinden Zamanın Dışından (Ankara: Heretik Yayınları, 2017), 147.

71 Murat Önderman, Sosyo-Kültürel Bir Fenomen Olarak Utanç (İstanbul: Filiz Kitabevi, 2009), 100.

72 Önderman, Türkiye'de Devlet Sosyal Kontrol ve Öznellik, 13.
} 
hatırda (bir fincan kahvenin kırk yıl hatırı vardır) kişiyi yukarıdaki örnekteki patrona veya veren ele karşı ahlaki borçlu kılan bir yan vardır. Anonim / yabancılarla ilişkilerin dışında aileye/çalışılan şirkete (veya etnisite-hemşerilik, din, ideoloji, millet, ülke, bölge vb.) karşı bu borçlu oluş, aileye veya çalışılan şirkete sadakati ölçüsünde korunma sağlayacaktır. Söz konusu aileye/şirkete karşı kişinin hakları hak hukuk dilinden ziyade, gördügü tekilsel ayrıcalıklarla (bağlamsal ahlakla) himaye edilecektir. Herhangi bir nesnel ilkeye veya değere dayanmadan, tarafların karşılıklı bă̆ımılı ilişkisinden doğan bu ahlak, anonim veya yabancılarla ilişkilerde aynı ahlaka uymayan ahlak dışı (amoral) bir bireyciliğe dönüșebilecektir.

\section{4. Güvensizliğin sürekli üretilmesi}

Türkiye'de kökleșmiş bir sosyal güvensizlik göze çarpmaktadır. Gerek kamu kurumuna, gerekse özel bir şirkete işi düşen kişiler, ilgili kurum/şirkette bir tanıdık bulmadıkça işini yapamayacağını, yapsa da gelişi güzel yapılacağını veya kandırılma korkusu ve güvensizliğini taşıyor. Bu tür ilişkilerde çeşitli soru veya soruşturmalarla hemen ortak bir tanıdık aranması, genellikle başvurulan bir yöntem.

Kurumlara üst düzey yönetici aranırken, yöneticide aranan özelliklerin başında/arasında çeşitli kamu kurumlarında fazla tanıdığı olması önem arz ediyor. Bu, kurumların, olası sorunlarını, tanıdık olmadan kolayca çözemeyeceğini düşünmesinden kaynaklanıyor. Bu açıdan güvensizlik akılcı olsa da olmasa da bir yönüyle paranoid bir nitelik arz ediyor. ${ }^{73}$ Yakın zamana kadar Türkiye'nin önde gelen pek çok şirketi, hatta holdinginde emekli general veya tecrübeli/emekli maliye/vergi müfettişi istihdamı, bu güvensizliğin bir göstergesi olarak okunabilir. Sebebi ne olursa olsun güvensizlik, kişileri/şirketleri savunmacı bir davranışa zorlamaktadır. ${ }^{74} \mathrm{Bu}$ da hem kendini, hem de çevresindeki kişi/şirketleri kontrol etmeye neden olan "çatışma kültürü"ne yol

73 Önderman, Türkiye'de Devlet Sosyal Kontrol ve Öznellik, 95.

74 Önderman, Türkiye'de Devlet Sosyal Kontrol ve Öznellik, 95. 
açmaktadır. ${ }^{75}$ Türkleri bir araya getiren iş-teşlik, aynı zamanda onların ayrıl-ış-ında da aynı işlevi görüyor. Söz konusu çatışma kültürünün bir türevi olan ay-r-ış-ma, toplumda yüksek güç mesafesinin sonucu gibi duruyor.

Türkiye'deki baskın bütüncül kültüre içkin olan otoritenin üstünlüğü, bir üst olarak "her bakımdan üstün" olmasını gerektirdiği için, bir-l-eş-en Türklerin ayrışması durumunda, otoriteye uzak olan taraf, otorite veya otoriteye daha yakın olan tarafından, "her bakımdan aşağılık" olarak görülmelerine neden oluyor. Bu bakımdan Türkler, bir iş tutarken ne ölçüde birleșmeye hız ve önem veriyorsa, yüksek güç mesafesi veya toplumsal güvensizliğin yüksek boyutlarda olması dolayısıyla ayrışma da o ölçüde hızlı ve sancılı gerçekleşmekte. Türklerin tarih boyunca devletlerinin "kendi içinden" yıkıldığına yönelik anlatının temel sebeplerini burada aramak yerinde olacaktır.

Sorumlulukların kesin sınırlarının çizilememesinden kaynaklı emeğin karşılığını alamaması nedeniyle gerek yaygın toplumsal güvensizlik, gerek ayrıntıya odaklanamama ve gerekse iş yerindeki güç mesafesinin yüksekliği, Ar-Ge çalışmalarına göstermelik düzeyde bir ilginin doğmasına neden olmaktadır. Aynı nedenlerle patent başvurularının yetersizliği, patentli ürünlerin üzerindeki devlet korumasının yetersizliği gibi nedenler bu tür güvensiz ortamın istenmeyen sonuçlarıdır. Güç mesafesinin yüksekliğinin yarattığı olumsuz havanın dışında gerek kamu ve gerekse özelde çalışanların yenilik yaratıcı fikirler (inovasyon) ileri sürmedeki isteksizliği veya ortak yapılan işlere katılımdaki gönülsüzlügün diğer bir nedeni de, verilen emeğin karşılığını alamamak veya daha da açıkçası emeğin çalınması olabilir.

Örneğin tiyatro oyununda, oyuna emek veren ancak oyuncu da olmayan hemen herkesin (1şıkçl, dekorcu, marangoz, terzi vs.), oyun sonunda oyuncularla birlikte sahneye çlkıp seyircileri selamlaması, oyuna emeği geçen istisnasız herkesin emeğinin takdir ve taltif edilmesidir. Emeği geçen her çalışanın takdiri film

75 Önderman, Türkiye'de Devlet Sosyal Kontrol ve Öznellik, 97. 
jeneriklerinden de örneklenebilir. Herkesin işin sonucu olarak aldığı ücretin dışında, sosyal yönden de tatmin edilmesi, işe bağlılıklarını, üretimlerini ve iş verimliliğini arttırıyor olsa gerek. Genelde Batı kökenli sanat alanında durum böyle. Ancak faydalı veya faydasız olması bir yana, kamu veya özel şirketlerde Ar-Ge'ye bir fikir sunulduğunda personelin takdir edilmesi neredeyse istisnadır. Bazı kamu kurumlarının yayınlarında da bunu gözlemleyebiliyoruz. Yayının (kitap, dergi, broşür, bülten vs.) ortaya çıkması sürecinde bir şekilde emeği geçen çalışanın adına, ilgili yayının hiçbir tarafında rastlanmaması, bunun yanında hiç ilgisi olmayan ve genellikle üst yönetici konumundaki kişilerin adlarına rastlanılması çok tipik bir örnektir.

\section{5. Genellik ve zamanı etkin kullanamama}

Türkiye'de şirketlerin faaliyet konusuna bakılması, genelliğin boyutlarının anlaşılmasında büyük ölçüde bize yardımcı olacaktır. Neredeyse yazılmayan faaliyet kalmamacasına pek çok alanın sıralanması, anlık gelişmelere göre ana faaliyet alanından sapılabilmeye açıklığı göstermektedir. Anlık gelişmelere açıklık, ister istemez şirketleri ayrıntılı alanlar üzerinde değil, genel geçer işlerin takibi noktasında hassas kılacaktır. Her an her şeye açıklık, siyasi ve ekonomik konjonktürün değişebilmesi ile doğrudan ilgilidir. Bu durum da, şirketleri bir alana gözü kapalı odaklanmaya değil, zamanını diğer anlık fırsatlardan da yararlanmaya itmektedir. Ekonomik rasyonaliteden ziyade siyasi rasyonalitenin gözetilmesi de yine baskın kültürün bir sonucudur. $\mathrm{Bu} \mathrm{da}$, ekonomik alanın siyasi alanın güdümünde olduğunu, özerkleşemediğini göstermektedir. ${ }^{76}$

Aynı durum devlet açısından da geçerlidir. Devlet görevlilerinin iş dünyasına geçişi noktasında ortaya çlkan yolsuzluk iddiaları karşısında devlet, ilgili kişi veya şirketlere karşı önlem geliştirmek yerine, tüm iş dünyasını ilgilendiren aşırı önlemlere başvurması, ${ }^{77}$ genellemenin bir başka boyutudur. Tarihsel dayanağını Yunus Emre'de de gördüğümüz bu dervişane

\footnotetext{
76 Buğra, Devlet ve İşadamları, 147-174.

77 Buğra, Devlet ve İșadamları, 166.
} 
özellik, iş zihniyetimizin temel taşlarından biri gibidir neredeyse: Elif okuduk ötürü, Pazar eyledik götürü...

Şirketlerin faaliyet alanları da bundan ayrı düşünülemez. Faaliyet konusunda şirketlerin yelpazeyi geniş tutması, bir işe yeterince odaklanamamadan ayrı düşünülemeyecek olan, zamanı etkin kullanamamayı da doğurmaktadır. Pek çok şeyin son güne ve son ana bırakılması, acelecilik olarak değil, zamanda etkinsizliği göstermektedir. Zamanın mekândaki tarihsel izdüşümü olan son yüzyıldaki Türk şehirlerine baktığımızda, tarihsel süreklilikteki bir kopuşa işaret etse de, gerek TOKI ve gerekse sivil şehircilik örnekleri zamanın yeni ruhuna uyum sağlayamadığının apaçık göstergeleridir. Estetik, özen ve ayrıntıdan kaçıldığı ölçüde büyük işlerin peşinde olan Türk iş zihniyetini şehirde yaşam alanı yerine rant üretirken görmek, sadece iş ve siyaset dünyasının değil, onu da yönlendiren baskın bütüncül ve tekilsel kültürün, evrensel hukuk kurallarına geçilmediği ve içselleştirme teknolojilerinin devreye sokulmadığı müddetçe kolay değişmeyecek bir özellik gibi durmaktadır.

\section{Sonuç}

Türklerin sanayi devrimine kadar, tarih boyunca hayvancılık ve tarımı savaşçılık temelinde örgütleyerek yükselen yıldızı, büyük ölçüde fiziki güçlerin bir-l-eş-tirilmesi sayesinde yaplabilecek işler olduğu içindi. Bir yapay güç (makine) devrimi olan sanayi devrimi, iş-lerin, insanların fiziki güçlerini bir-l-eş-ti-rerek (işteşlikle) yapılabilme zorunluluğunu ortadan kaldırdı. Çünkü işler, artık insanların fiziken bir-l-eş-mesi ile değil, makinelerin yardımıyla yapılmaya başlanmıştı. Bu anlamda Türk, iş-l-ev-siz kaldı, önce iş-ini, sonra da ev-ini yitirdi.

Burada tarihsel bir dönemlendirme ve isimlendirme önermek istiyorum. Sanayi devrimine kadar olan Türklerin tarihini hızlı fiziki birleşme çağı olarak teklif ediyorum. Henüz başlayamayan çağı ise bilişsel ve düşünsel birleşmeler çağı... Bilişsel ve düşünsel birleşmeler çă̆ı henüz başlamadı. Arada kalan ve içinde bulunduğumuz dönem ise fetret dönemi. Sanayi Devrimine kadar ve söz konusu özellikleri 
dolayısıyla Türkler tarihin kurucu unsuru olmuşken, bu tarihten sonra kurucu unsur olma iş-levini yitirmiş, eski iş-teşlik onlara yeni bir söz söyleme anlamında yeni bir ev vermemiştir. Türkler için yeni ev, onların tarihi özellikleri olan iş-teşliği (birliktelik) veri alarak bilişsel ve düşünsel birleşmeler çağına geçmek olacaktır. Türkler, henüz boșlukta, bilişsel ve düşünsel birleşmeler çağının arefesindedir.

Türkler için yaşamak ve yeryüzü bir anlam ifade ediyorsa, bugüne kadar olduğu gibi yüksek hızda fiziki birleşme kapasitesinin yerini, bilişsel ve düşünsel birleşmeler almadıkça, Türklerin yeni dünyaya 'yeni bir söz' söylemesinin imkânı da kalmamış olacaktır. Fiziki birleşmedeki tarihsel yetkinliğin psikolojik nedenleri (içten yıkılma) henüz ele alınmamıștır. Sorun, fiziki birleşmede değil, gerektiğinde uzlaşarak ayrışamama gibi görünmektedir. $\mathrm{Bu}$ sorun çözülemezse bilişsel ve düşünsel birleşmeler çağına da geçilemeyeceği söylenebilir. Siyasetin çatışmacı dili, sorunu anlamayı ve çözmeyi geciktirmektedir.

Hızlı fiziki birleşme kapasitesini yeniden zorlamak, bir bakıma Osmanlı'nın kanun-u kadim (tradisyonalist-gelenekselci) yöntemini ihya etmek olarak da anlaşılabilir. Ancak kabul edilmesi gerekir ki, zamanın değişmesi sebebiyle bu (geriye doğru bakış) yöntemin işlevini yitirdiği aşikardır. Değişimi artık ihtilal (halden hale geçiş) olarak görmeyip, bilişsel ve düşünsel birleşmeler için, iş zihniyetinin üzerinde temellendiği kolektivist ve tekilsel kültürün açmazları, başta psikoloji, sosyoloji, siyaset, iktisat, tarih, dil, felsefe ve kültür olmak üzere ilgili alanlar tarafından iş-teşlik halinde (birlikte) teşhis edilip çözümler önerilebilmesinin önü açılmalıdır.

$\mathrm{Bu}$ anlamda toplumların krizini (crise), kritik (critique) edememe olarak gören Besim F. Dellaloğlu, ${ }^{78}$ Batı'nın, kendisini kritik (eleştiri) üzerinden var ettiğini ima eder görünmektedir. Dellaloğlu'na göre toplumun asıl krizi, eleştiri eksikliği veya yokluğudur. Bir fetret dönemi olarak görülebilecek Türklerin içinde bulunduğu bu krizden, ancak güçlü bir eleştiri ortamının

\footnotetext{
78 Besim F. Dellaloğlu, Modernleşmenin Zihniyet Dünyası: Bir Tanpınar Fetişizmi (Ankara: Kadim, 2016), 120.
} 
sağlanması halinde çıkılabileceğidir. Türkler, fiziki güçleri birleştirme yerine, artık eleştirel düşünce ortamını yaratarak bilişimsel iş-teşliğinin önünü açarsa, zaten kendiliğinden kendi önü de açılmış olacaktır. Tıpkı, 1142 yılında "Müslümanları askeri alanda değil de entelektüel alanda yenmek gerektiği düşüncesini ortaya atan" Cluny tarikatının İspanya müfettişi Muhterem Pierre'in ironisinde ${ }^{79}$ olduğu gibi.

${ }^{79}$ Jacques Le Goff, Ortaçağda Entelektüeller, çev. Mehmet Ali Kılıçbay (İstanbul: Türkiye İş Bankası Kültür Yayınları, 2017), 22. 


\section{Kaynakça}

Adanır, Oğuz. Eski Dünyaya Yeni Bir Bakış. Ankara: Doğu Batı Yayınlarl, 2010.

Altuğ, Taylan. Dile Gelen Felsefe. İstanbul: YKY, 2017.

Ayas, Güneş. Müzik Sosyolojisi: Sorunlar-Yaklaşımlar-Tartışmalar. İstanbul: Doğu Kitabevi, 2015.

Aygül, Hasan H. Zihniyet Din ve İktisat. İstanbul: Açılım Kitap, 2014.

Aytmatov, Cengiz. Toprak Ana. Çeviren Refik Özdek. İstanbul: Ötüken Neşriyat, 2018.

Bachelard, Gaston. Mekânın Poetikası. Çeviren Alp Tümertekin. İstanbul: Kesit Yayınları, 1996.

Bion, Wilfred R. Experiences in Groups and Other Papers. New York: Brunner-Routledge, 2004.

Brusadin, Leandro B. "The Gift Theory of Marcel Mauss and the Potlatch Ritual." The Routledge Handbook of Hospitality Studies içinde, editör Conrad Lashley, London: Routledge, ss. 298-310 (27.11.2017), 2016.

Buğra, Ayşe. Devlet ve İşadamları. Çeviren Fikret Adaman. İstanbul: İletişim, 2016.

Buğra, Ayșe. Devlet-Piyasa Karşıtığının Ötesinde. Çeviren Bahadır Sina Şener. İstanbul: İletişim, 2010.

Butor, Michel. Michel Butor Üstüne Doğaçlamalar. Çeviren İsmail Yerguz. İstanbul: YKY, 1996.

Dellaloğlu, Besim F. Modernleşmenin Zihniyet Dünyası: Bir Tanpınar Fetişizmi. Ankara: Kadim, 2016.

Dellaloğlu, Besim F. Toplumsalın Yeniden Yapılanması. İstanbul: Bağlam Yayıncılık, 1998. 
Dellaloğlu, Besim F. Zamanın İçinden Zamanın Dışından. Ankara: Heretik Yayınları, 2017.

Demir, Gökhan Y. Sosyal Bir Fenomen Olarak Dilin Belirsizliği. İstanbul: İthaki, 2015.

Deutscher, Guy. Dilin Aynasından. Çeviren Cemal Yardımcı. İstanbul: Metis, 2013.

Duben, Alan. "The Significance of Family and Kindship in Urban Turkey." Sex Roles, Family and Community in Turkey içinde, editör Çiğdem Kağıtçıbaşı, Bloomington: Indiana University Turkish Studies, ss. 73-100, 1982.

Göçer, Kenan. "Ahiliği Potlaç Kültürü Üzerinden Yeniden Düşünmek." Selçuk Üniversitesi Edebiyat Fakültesi Dergisi, sy. 37 (2017): 465-476.

Göçer, Kenan. “Armağan Kültürü Açısından Saatleri Ayarlama Enstitüsü'nün İktisadi Zihniyeti Üzerine." Sosyoloji Divanı, sy. 10 (2017): 253-268.

Göçer, Kenan. “Kuran'daki Arz ve Dünya Kavramlarının Osmanlı İktisat Zihniyeti Üzerine Etkisi." 15. Uluslararası Türk Dünyası Sosyal Bilimler Kongresi, 11-12 Eylül 2017, Gagauzya, Moldova, (2017d): 70-82.

Göçer, Kenan. "Melâmîliğin Türklerin İktisat Zihniyeti Üzerindeki Uzun Dönem Etkisi." Türk Dünyası Araştırmaları 115, sy. 227 (2017): 115-132.

Göka, Erol. Türk Grup Davranışı. Ankara: Aşina Kitaplar, 2006.

Göka, Erol. Türklerde Liderlik ve Fanatizm. İstanbul: Timaş, 2009.

Göka, Erol. Türklerin Psikolojisi. İstanbul: Timaş, 2011.

Gökalp, Ziya. Türk Uygarlığı Tarihi. Hazırlayan Yusuf Çotuksöken. İstanbul: İnkilâp Kitabevi, 1991. 
Göktaş, Hüseyin Rahmi. Bensenog Türkçenin Ruhu. İstanbul: Külliyat Yayıncılık, 2016.

Göktaş, Hüseyin Rahmi. Runa Simi. İstanbul: İz Yayıncılık, 2010.

Göktaş, Hüseyin Rahmi. Zihin Evreni. İstanbul: İz Yayıncılık, 2011.

Heper, Metin. Türkiye'de Devlet Geleneği. Çeviren Nalan Soyarık. İstanbul: Doğu Batı Yayınları, 2015.

Hürriyet

Gazetesi,

http://www.hurriyet.com.tr/ekonomi/turkiyedeki-

isletmelerin-yuzde-95i-aile-sirketi-40599291 (29.05.2018).

Hofstede, Geert, Gert J. Hofstede ve Michael Minkov. Cultures and Organizations: Software of the Mind. New York \& Chicago: McGrawHill, 2010.

İnalcık, Halil. Osmanlı Imparatorluğu Klasik Çă̆ (1300-1600). İstanbul: YKY, 2003.

İnalcık, Halil. Osmanlı İmparatorluğu Toplum ve Ekonomi. İstanbul: Eren Yayıncılık, 1996.

Kamu Mali Yönetimi ve Kontrol Kanunu, Kanun No: 5018, Resmî Gazete Tarih: 24.12.2003, Sayı: 25326.

Karatani, Kojin. Dünya Tarihinin Yapısı. Çeviren Ali Karatay. İstanbul: Metis, 2017.

Le Goff, Jacques. Ortaçağda Entelektüeller. Çeviren Mehmet Ali Kılıçbay. İstanbul: Türkiye İş Bankası Kültür Yayınları, 2017.

Mauss, Marcel. Sosyoloji ve Antropoloji. Çeviren Özcan Doğan. Ankara: Doğu Batı Yayınları, 2006.

Mautner, Thomas. "Particularism." The Penguin Dictionary of Philosophy, London: Penguin Books, 1997. 
Muhasebei Umumiye Kanunu, Kanun No: 1050, Resmî Gazete Tarih: 9.6.1927, Sayı: 606 .

Önderman, Murat. “Türkiye'de Tekilci Kültür, Hukukilik ve Armağan Ekonomisi." İstanbul Üniversitesi Siyasal Bilgiler Fakültesi Dergisi, sy. 25 (2001): 157-208.

Önderman, Murat. Sosyo-Kültürel Bir Fenomen Olarak Utanç. İstanbul: Filiz Kitabevi, 2009.

Önderman, Murat. Türkiye'de Devlet Sosyal Kontrol ve Öznellik. İstanbul: Filiz Kitabevi, 2007a.

Önderman, Murat. Türkiye'de Paranoid Ethos. İstanbul: Filiz Kitabevi, 2007b.

Polanyi, Karl. Büyük Dönüşüm. Çeviren Ayșe Buğra. İstanbul: İletişim, 2016.

Rehn, Alf. "Gifts, Gifting and Gift Economies." The Routledge Companion to Alternative Organization içinde, editör Martin Parker v.dğr., London: Routledge, 195-209, (27.11.2017), 2013.

Roux, Jean-Paul. Türklerin Tarihi Pasifik'ten Akdeniz'e 2000 Yll. Çeviren Lale Arslan Özcan. İstanbul: Kabalcı, 2015.

Sayar, Ahmet G. Osmanlı İktisat Düşüncesinin Çağdaşlaşması. İstanbul: Ötüken Neşriyat, 2000.

Sayar, Ahmet G. Osmanlı'dan 21. Yüzyıla. İstanbul: Ötüken Neşriyat, 2001.

Saydam, M. Bilgin. Deli Dumrul'un Bilinci. İstanbul: Metis, 2013.

Sombart, Werner. Yahudiler ve Modern Kapitalizm. Çeviren Sabri Gürses. İstanbul: Küre, [1902] 2016. 
Sunar, Lütfi. "A Weberian Critique of Weber: Re-Evaluation of Sabri F. Ülgener's Studies on Socio-Economic Structure of Turkey." Economics and Political Economy 2, sy. 1 (2015): 186-196.

Sunar, Lütfi. "Weber'in İktisat Sosyolojisi: Uygarlığı Anlamanın Anahtarı Olarak İktisadi Zihniyet." Sosyoloji Konferansları, sy. 45 (2012): 19-42.

Tabakoğlu, Ahmet. Íktisat Tarihi. İstanbul: Kitabevi, 2005a.

Tabakoğlu, Ahmet. İslâm İktisadı. İstanbul: Kitabevi, 2005b.

Tabakoğlu, Ahmet. Türk İktisat Tarihi. İstanbul: Dergâh Yayınları, 2010.

Tahir, Kemal. Devlet Ana. İstanbul: İthaki, 2018.

Tanpınar, Ahmet Hamdi. Sahnenin Dışındakiler. İstanbul: Dergâh Yayınları, 1999.

Tawney, Richard H. Religion and the Rise of Capitalism. New York: Harcourt, Brace and World Inc., [1926] 1954.

Türk Dil Kurumu, "büyük ünlü uyumu”, http://www.tdk.gov.tr/index.php?option=com content\&id=177:Buyuk-Unlu-Uyumu\&catid=50:yazmkurallar (7.05.2018).

Türk Dil Kurumu, "küçük ünlü uyumu", http://www.tdk.gov.tr/index.php?option=com_ content\&view=article\&id=178:Kucuk-UnluUyumu\&catid=50:yazm-kurallar\&Itemid=132 (7.05.2018).

Türkiye Cumhuriyeti Anayasası, Kanun No: 2709, Resmî Gazete Tarih: 9.11.1982, Sayı: 17863 (Mükerrer).

Ülgener, Sabri F. Íktisadi Çözülmenin Ahlak ve Zihniyet Dünyası. İstanbul: Derin Yayınları, [1951] 2006. 
Kenan GÖÇER

Ülgener, Sabri F. Zihniyet ve Din: İslâm Tasavvuf ve Çözülme Devri Íktisat Ahlâkı. İstanbul: Derin Yayınları, [1981] 2015.

Weber, Max. The Protestant Ethic and the Spirit of Capitalism. Çeviren Talcott Parsons. London \& New York: Routledge, [1904] 2005.

White, Jenny B. Para ile Akraba. Çeviren Aksu Bora. İstanbul: İletişim, 2015. 